\title{
Corporate Debt Maturity and Stock Price Crash Risk
}

DOI:

10.1111/eufm. 12134

\section{Document Version}

Accepted author manuscript

Link to publication record in Manchester Research Explorer

\section{Citation for published version (APA):}

Dang, V. A., Lee, E., Liu, Y., \& Zeng, C. (2018). Corporate Debt Maturity and Stock Price Crash Risk. European Financial Management, 24(3), 451-484. https://doi.org/10.1111/eufm.12134

\section{Published in:}

European Financial Management

\section{Citing this paper}

Please note that where the full-text provided on Manchester Research Explorer is the Author Accepted Manuscript or Proof version this may differ from the final Published version. If citing, it is advised that you check and use the publisher's definitive version.

\section{General rights}

Copyright and moral rights for the publications made accessible in the Research Explorer are retained by the authors and/or other copyright owners and it is a condition of accessing publications that users recognise and abide by the legal requirements associated with these rights.

\section{Takedown policy}

If you believe that this document breaches copyright please refer to the University of Manchester's Takedown Procedures [http://man.ac.uk/04Y6Bo] or contact uml.scholarlycommunications@manchester.ac.uk providing relevant details, so we can investigate your claim.

\section{OPEN ACCESS}




\title{
Corporate Debt Maturity and Stock Price Crash Risk
}

\author{
Viet Anh Dang, Edward Lee, Yangke Liu, and Cheng Zeng ${ }^{1}$
}

Forthcoming in European Financial Management

\begin{abstract}
We find that firms with a larger proportion of short-term debt have lower future stock price crash risk, consistent with short-term debt lenders playing an effective monitoring role in constraining managers' bad-news-hoarding behavior. The inverse relation between short-maturity debt and future crash risk is more pronounced for firms that are harder to monitor due to weaker corporate governance, higher information asymmetry, and greater risk-taking. These findings suggest that short-term debt substitutes for other monitoring mechanisms in curbing managerial opportunism and reducing future crash risk. Our study implies that short-maturity debt not only preserves creditors' interests, but also protects shareholders' wealth.
\end{abstract}

Keywords: Debt maturity, Stock price crash risk, Corporate governance, Information asymmetry JEL Classification: $G 3, G 12, G 14$

\footnotetext{
${ }^{1}$ All authors are based at Alliance Manchester Business School, University of Manchester, M13 9SS, UK. Viet Anh Dang, Vietanh.Dang@manchester.ac.uk (+44-161-275-0438); Edward Lee, Edward.Lee@manchester.ac.uk (+44161-275-4564); Yangke Liu, Yangke.Liu@postgrad.mbs.ac.uk (+44-161-306-8783); Cheng Zeng (corresponding author), Cheng.Zeng@manchester.ac.uk (+44-161-306-3438).

We gratefully acknowledge the constructive comments of John Doukas (the Editor) and two anonymous referees on the earlier version of the paper. We are also grateful for the helpful comments from Michael Brennan, Marie Dutordoir, Susanne Espenlaub, Ning Gao, Maria Marchica, Roberto Mura, Konstantinos Stathopoulos, Norman Strong, Karin Thorburn, and participants at the European Financial Management Association 2016 Annual Conference, the 2016 FMA Annual Meeting, the 2016 Vietnam International Conference in Finance, as well as participants of the faculty research seminar at Fudan University, Shanghai. All remaining errors are our own.
} 


\section{Introduction}

Debt is one of the primary means of capital acquisition for firms in the US and around the world (e.g., Graham et al., 2015; Öztekin, 2015). In the context of debt contracting, the structure of debt maturity significantly influences the decision making of both firms and investors. The existing academic literature on debt maturity comprises two pathways. One stream of literature has extensively documented the determinants of firms' debt maturity choices (e.g., Barclay and Smith, 1995; Guedes and Opler, 1996; Stohs and Mauer, 1996; Ozkan, 2000; Datta et al., 2005; Antoniou et al., 2006; Brockman et al., 2010; Custódio et al., 2013). The other strand of literature investigates the interaction between debt maturity and other corporate policies, including financial leverage (Barclay et al., 2003; Johnson, 2003), debt covenants (Billett et al., 2007), cash holdings (Harford et al., 2014), and real investment (Aivazian et al., 2005; Duchin et al., 2010; Almeida et al., 2011). Despite the growing awareness of the role of debt maturity in shaping corporate finance and investment policies, relatively limited research is available on whether and how the monitoring of short-term debt lenders affects shareholder wealth through its impact on stock prices. Our study fills this gap in the literature by examining the effect of short-term debt on future stock price crash risk.

Stock price crash refers to an extreme collapse in equity value that causes a severe decline in shareholders' wealth. This downside risk is of serious concern to investors and firms alike because it affects their risk management and investment decision making. Prior literature suggests that the primary cause of stock price crash is managers' tendency to hoard and withhold unfavorable information from outsiders in the presence of potential agency problems (e.g., Jin and Myers, 2006; Kothari et al., 2009; Hutton et al., 2009; Callen and Fang, 2015b). Incentivized by empire building, as well as career and compensation concerns, managers may attempt to conceal bad news over an extended time, and upon subsequent revelation of such accumulated information the market value of their firms corrects sharply downward, leading to stock price crashes. 
We hypothesize that short-term debt can reduce a firm's stock price crash risk for the following reasons. Since the repayment of debt financing is fixed, lenders face an asymmetric payoff, that is, they are exposed to downside credit risk with a capped upside payoff. Under such circumstances, the timely disclosure of bad news is of particular importance to debtholders. Compared to long-term debt, debt with short maturities involves more frequent renewal or refinancing (Myers, 1977; Diamond, 1991a), thus serving as an effective tool for lenders to monitor managerial behavior and enhance information transparency (Ranjan and Winton, 1995; Stulz, 2001; Datta et al., 2005; Graham et al., 2008). This is because incomplete debt contracts only allocate lenders' control rights ex ante, hence giving lenders strong incentives to use the credible threat of not renewing debt contracts to deter managers' opportunistic behavior ex post (Giannetti, 2003). Lenders of short-term debt, in particular, can protect their rights by requiring managers to provide timely and reliable information about firms' financial condition and future investments when negotiating the renewal of debt contracts. This distinct feature of short-term debt enhances managerial information revelation, curbs the likelihood of bad news hoarding, and hence reduces future stock price crash risk. While it is possible that long-term debt holders can also play a monitoring role, especially through the use of debt covenants, the monitoring function of long-term debt tends to be less effective than that of short-term debt, because long-term debt holders can act only when a covenant violation occurs (Rajan and Winton, 1995). As a result of this limitation, the ability of long-term debtholders to curb managerial hoarding of adverse information may be relatively weaker than that of short-term debtholders. Overall, our arguments predict that short-maturity debt is negatively related to future stock price crash risk.

To test this prediction, we regress future stock price crash risk on short-term debt, while controlling for several important firm-specific determinants of crash risk. Consistent with prior studies (e.g., Chen et al., 2001; Hutton et al., 2009; Kim et al., 2011a, 2011b; Kim and Zhang, 2016), we use two main measures of stock price crash risk, namely (i) the negative conditional skewness of firm-specific weekly returns and (ii) the "down-to-up volatility" of firm-specific weekly returns. Following the debt maturity literature, we measure short-maturity debt as the fraction of debt due within three years, which is 
a well-established cutoff point for computing the short-term debt ratio (e.g., Barclay and Smith, 1995; Johnson, 2003; Brockman et al., 2010; Harford et al., 2014).

We document empirical evidence in support of our main hypothesis. Using a sample of 7,712 unique firms and 53,052 firm-year observations from 1989 through 2014, we find that firms using more short-term debt exhibit lower future stock price crash risk. This finding is in line with managers being less likely to conceal and hoard bad news in the presence of external monitoring by short-term debt lenders. Our results are robust to a battery of tests addressing endogeneity concerns and those using alternative measures of key variables, including crash risk and short-maturity debt. Importantly, using a sample of new debt issues, we find that the maturities of those debt issues are positively related to future stock price crash risk, which further strengthens our main inference of a causal relationship between short-term debt and future crash risk.

We next investigate whether short-term debt effectively substitutes for other monitoring mechanisms in curbing managerial bad-news-hoarding behavior. These additional empirical analyses are motivated by the extant studies on the agency perspective of debt maturity (e.g., Rajan and Winton, 1995; Datta et al., 2005). If short-term debt indeed reduces stock price crash risk due to creditors' monitoring, then we would expect such an effect to make a bigger difference among firms that are more susceptible to agency problems and information asymmetry. Consistent with this conjecture, we show that the mitigating effect of short-term debt on crash risk is more pronounced when firms have weaker governance, such as less (long-term) institutional ownership and lower shareholder rights. Meanwhile, we find that the negative relation between short-term debt and future crash risk is stronger among firms with a higher degree of information asymmetry, measured by analyst forecast errors, a dispersion in analyst earnings forecasts, and research and development (R\&D) intensity. Finally, we show that the inverse relation between short-term debt and future crash risk is more salient for firms that engage in greater risktaking, including those with higher leverage or without bond rating. Taken together, these findings shed light on how short-term debt lenders can substitute other corporate monitoring mechanisms in mitigating managerial discretion and future stock price crash risk. 
Our paper contributes to at least two strands of literature. First, to the best of our knowledge, this is the first study to investigate the equity market consequences of corporate debt maturity, with a focus on the impact of short-term debt on high moments of stock return distribution (i.e., extreme negative returns). Prior research suggests that short-maturity debt plays a significant role in reducing agency costs (Myers, 1977; Childs et al., 2005; Datta et al., 2005), risk-taking incentives (Barnea et al., 1980; Leland and Loft, 1996; Brockman et al., 2010), and audit risk (Gul and Goodwin, 2010) through the frequent and stringent monitoring of external creditors (Rajan and Winton, 1995; Stulz, 2001). However, there has been little, if any, research testing the impact of short-term debt on corporate disclosure behavior and, ultimately, shareholder wealth. Our empirical evidence therefore extends this literature by showing that short-term debt can reduce stock price crash risk through curbing managers' bad-news-hoarding activities.

Second, our study enriches a growing stream of research on stock price crash risk. As a special feature of stock return distribution, the issue of stock price crash risk is attracting increased attention among academics and practitioners. Recent studies show that various internal and external factors influence firms' stock price crash risk, consistent with the bad-news-hoarding argument (see Habib et al., 2016 for a literature review). Among the internal mechanisms affecting managerial incentives to withhold adverse information are executive compensation (Kim et al., 2011a), tax avoidance techniques (Kim et al., 2011b), accounting conservatism (Kim and Zhang, 2016), and chief executive officer (CEO) overconfidence (Kim et al., 2016). Examples of external monitoring mechanisms include institutional ownership (An and Zhang, 2013; Callen and Fang, 2013), accounting standards (DeFond et al., 2014), short-selling (Callen and Fang, 2015a), religion (Callen and Fang, 2015b), auditing service (Habib and Hasan, 2015; Callen and Fang, 2016), and stock liquidity (Chang et al., 2016). Our study adds to this literature by providing novel evidence of how (i) a corporate financial policy such as debt maturity structure and (ii) creditors across a parallel capital market can exert a significant impact on stock price crash risk, above and beyond the effects of several factors affecting crash risk reviewed above.

Our paper is closely related to Boubaker et al. (2014) and Andreou et al. (2016), who document evidence of the influences of corporate governance attributes on stock price crash risk. However, our 
study differs from them in an important way. While we examine the monitoring role of short-term debt, an external corporate governance mechanism, in mitigating crash risk, Boubaker et al. (2014) and Andreou et al. (2016) mainly focus on the role of internal governance mechanisms and particularly those relating to shareholders and managers (e.g., controlling shareholders, ownership structure, board structure and processes, and managerial incentives). Our study is the first to provide systematic evidence that shortmaturity debt plays an effective monitoring role in constraining managers' bad news hoarding and thus reducing stock price crash risk. Hence, we extend prior studies by showing that shareholders can benefit from the monitoring function of external creditors and in particular short-term debt lenders. In addition, our study is of practical relevance as it shows how debt maturity structure may have important implications for stock selection by equity investors.

The rest of the paper is organized as follows. Section 2 reviews prior research on debt maturity and stock price crash risk and develops our hypotheses. Section 3 describes the sample and research design. Section 4 presents the empirical results. Section 5 concludes.

\section{Related Literature and Hypotheses}

\subsection{Short-maturity Debt}

The finance literature has identified several benefits of short-term debt. From lenders' perspective, a distinct advantage of short-maturity debt is that it gives them control rights ex post, with which they can effectively monitor borrowers. Due to incomplete debt contracting, lenders generally do not have control rights over every future contingency in the initial contract terms. Debt with short maturities, however, provides them with better protection and greater bargaining power because they can threaten borrowers with rejection of refinancing when the short-term debt comes up for renewal (Giannetti, 2003). Put differently, the frequent renegotiations and renewals of short-maturity debt help fill the void of contractual incompleteness by allocating lenders' control rights ex post (Roberts and Sufi, 
2009; Roberts, 2015). This advantage of short-term debt prompted Myers (1977, p. 159) to suggest that "permanent debt capital is best obtained by a policy of rolling over short maturity debt claims."2

A key benefit of short-term debt is that it exercises a monitoring function over borrowers, thus reducing information problems and increasing corporate transparency. Prior research shows that shortmaturity debt subjects managers to more frequent and stringent creditor monitoring (Stulz, 2001; Datta et al., 2005), thereby forcing more timely information disclosure (Rajan and Winton, 1995). The reason is that short-term debt lenders must periodically evaluate the borrowing firm's creditworthiness, especially during the debt renegotiation and renewal processes. This feature of short-term debt gives its lenders an important advantage over long-term debt lenders, who may also play a monitoring role but mainly do so by relying on ex ante covenant terms to gather limited and verifiable information. Rajan and Winton (1995) argue that short-maturity debt provides lenders with the flexibility and unlimited ability to act, even when the debt covenants have not been violated. Specifically, the frequent scrutiny of short-term debt lenders leads to greater disclosure of company information, including relevant information that may be unverifiable and imperfectly correlated with covenant terms. ${ }^{3}$

Empirical evidence provides support for the notion that short-term debt plays an important role in scrutinizing firms and alleviating information asymmetry. Graham et al. (2008) show that banks shorten

\footnotetext{
${ }^{2}$ From a borrowing firm's perspective, although short-term debt exposes the firm to refinancing risk (Diamond, 1991a), it can help alleviate incentive problems arising from the conflicts of interest between shareholders and creditors. For instance, existing studies suggest that short-term debt helps reduce underinvestment (Myers, 1977; Childs et al., 2005), asset substitution (Leland and Toft, 1996), and excessive risk-taking (Barnea et al., 1980; Childs et al., 2005; and Brockman et al., 2010).

${ }^{3}$ However, some research suggests that under certain circumstances long-term debt is able to discipline management effectively. For instance, Rajan and Winton (1995) argue that long-term debt may be preferable to short-term debt if the former's covenants depend on publicly available or less costly information. On the other hand, some studies contend that the liquidity and refinancing risk of short-term debt may incentivize managers to conceal negative information (Roberts and Sufi, 2009; Fields et al., 2016). Since long-term debt may not impose such a refinancing pressure, it may be more effective in curbing firms' misreporting behavior. Nevertheless, these arguments are likely to bias against us finding evidence of an inverse relationship between short-maturity debt and stock price crash risk.
} 
the maturities of loans provided to firms that have previously engaged in financial misreporting, consistent with lenders using short-term debt to enhance managerial scrutiny and information gathering in an environment of increased risk and information asymmetry. In a similar vein, Gul and Goodwin (2010) demonstrate the importance of short-maturity debt in improving corporate transparency, especially among risky firms. They find that short-term debt is negatively related to audit risk and that this relation is more pronounced for firms with low quality ratings. The latter finding suggests that the monitoring of shortmaturity debt has a greater impact on the transparency of firms considered more uncertain and risker by credit rating agencies. While these studies show how creditors' monitoring reduces firms' information asymmetry, they have not investigated whether the use of short-term debt influences stock price crash risk and shareholder wealth, as we do in this paper.

\subsection{Stock Price Crash Risk}

A large and growing body of literature has examined what determines stock price crash risk, reflecting the increasing importance of this issue to academics and practitioners (e.g., Habib et al., 2016). Chen et al. (2001) find that the trading volumes and returns over the past several months can forecast future crashes. Importantly, Jin and Myers (2006) theoretically show that inside managers who are in charge of revealing firm-specific information have incentives to absorb certain downside risk by withholding bad news. However, once the hoarded bad news reaches a critical threshold, managers may no longer be able to conceal bad news and the revelation of such information to the public becomes inevitable. This revelation in turn leads to extreme downward stock price corrections or crashes that are manifested as a long left tail in the distribution of returns.

Existing studies identify various determinants of future stock price crash risk and provide empirical evidence in support of the bad-news-hoarding argument. Jin and Myers (2006), Hutton et al. (2009), and Callen and Fang (2015b) show that information opacity and low transparency, particularly due to the use of discretionary accruals or accounting irregularities, lead to higher future crash risk. In a similar vein, Kim and Zhang (2016) find that a high degree of conditional conservatism neutralizes 
managers' tendency to delay bad news and accelerates good news recognition, thus lowering future crash risk. While those studies provide direct evidence in favor of the bad-news-hoarding argument, other works have documented additional evidence of several internal factors affecting crash risk via the badnews-hoarding channel. For instance, Kim et al. (2011a) argue that equity incentives induce managers to purposely hide negative information and manipulate market expectations, leading to an increase in future crash risk. Similarly, Xu et al. (2014) find that executives who enjoy excess perks are more likely to conceal bad news, thus resulting in higher future crash risk. Kim et al. (2011b) show that corporate tax avoidance increases crash risk because the tax avoidance techniques used by managers reduce corporate transparency. On the other hand, Kim et al. (2014) argue that managers committed to corporate social responsibility tend to maintain greater transparency and have less incentive to withhold bad news, which in turn leads to a lower probability of price crashes. However, Kim et al. (2016) show that overconfident CEOs tend to overestimate and misperceive negative net present value (NPV) projects, thus leading to an accumulation of bad performance and unfavorable information and, subsequently, higher stock price crash risk. Recent studies find that several governance mechanisms play an important role in determining crash risk. Boubaker et al. (2014) argue that firms with substantial excess control rights due to the presence of large controlling shareholders tend to disclose less firm-specific information and therefore experience more stock price crashes. In another study examining several attributes of corporate governance, Andreou et al. (2016) find that crash risk is positively related to CEO stock option incentives but is negatively associated with board size and inside directors' ownership. Our paper is related to those two studies, although we focus on an external governance mechanism across capital markets and associated with a different class of investors, namely external creditors and particularly short-term debt lenders.

In parallel, several studies highlight the influence of external monitoring mechanisms on future stock price crash risk. For instance, DeFond et al. (2014) find that the adoption of better accounting standards reduces future crash risk by improving the disclosure of firm-specific information and comparability. An and Zhang (2013) and Callen and Fang (2013) both show that the presence of 
institutional investors can improve governance monitoring mechanisms, thereby constraining managerial discretion and reducing future crash risk. Specifically, institutional ownership of dedicated investors can limit managers' ability to conceal unfavorable news, while transient institutional holdings incentivize managers to hide bad news to prevent transient investors from large short-term selling. Similarly, Chang et al. (2016) show that stock liquidity gives rise to crash risk because high liquidity attracts more transient investors, who focus on firms' short-term earnings and hence induce managers to withhold adverse information. On the other hand, Callen and Fang (2015a) contend that sophisticated short sellers can identify managers' bad news hoarding and seek profit from those firms; therefore, high levels of shortselling inflate future price crash risk. Callen and Fang (2015b) further find that strong religion acting as a social norm can inhibit managers' bad-news-hoarding activities and render lower stock price crash risk. Recently, Callen and Fang (2016) provide evidence that auditor tenure reduces the likelihood of stock price crashes, consistent with the auditor-client relationship enabling auditors to develop client-specific knowledge and enhancing their ability to deter and detect managerial withholding of adverse information. Although the above studies demonstrate several external monitoring mechanisms affecting the likelihood of future stock price crashes, they have not examined the role that external financing decisions, especially those regarding the choice of debt maturity, plays in reducing stock price crash risk. It is this gap that our study seeks to fill.

\subsection{Hypothesis Development}

A substantial body of research suggests that debt plays an important role in corporate governance, in large part through its reliance on contractual provisions, which require the borrowers to meet minimum financial criteria, increase information disclosure, and operate within bounds specified by creditors (e.g., Williamson, 1988). Debt contracting terms, especially restrictive covenants in a loan contract, are largely written on information from the borrowers' financial statements. Thus, debt holders, including banks, have an incentive to monitor the financial statements provided by the borrowers in order to detect any accounting irregularities in a timely manner and protect their financial stake in the borrowers (e.g., Fama, 
1985; Diamond, 1991b; Rajan and Winton, 1995). However, there is also a significant amount of loan research arguing that monitoring by debt holders, particularly banks, may not necessarily improve the borrowers' information transparency because the banks can achieve information monopoly due to their private access to inside information of the borrowers (Sheard, 1989; Boot, 2000; Vashishtha, 2014). This argument is corroborated by Dass and Massa (2011), who suggest that increased monitoring by banks creates a higher level of information asymmetry between borrowers and other market participants, leading to lower stock liquidity. One possible reason for the inconclusive findings regarding the relation between debt financing and information transparency is the failure of prior research to take debt maturity structure into account, given the monitoring effect can differ substantially among different types of debt.

We therefore focus on the relation between debt maturity and stock price crash risk and formulate our hypotheses by intersecting the intuitions associated with the two strands of literature reviewed above (i.e., those on debt maturity and stock price crash risk). Short-term debt subjects managers to frequent monitoring, thus effectively reducing managerial discretion and enhancing information disclosure (Rajan and Winton, 1995). While it is possible that long-term debt holders can play a monitoring role (see footnote 2 above), they are generally less effective monitors than short-term debt holders. Short-term debt lenders are able to scrutinize borrowers and gather information about their financial conditions and future prospects, especially when the short-term debt comes up for renewal and borrowers' creditworthiness is re-evaluated (Graham et al., 2008). ${ }^{4}$ Overall, the stringent monitoring of short-term debt forces firms to release relevant and reliable information that is likely to be above and beyond the disclosure required by covenant terms. Importantly, the frequent scrutiny by short-term debt lenders and debt markets restrains managers from arbitrarily concealing bad news. Put simply, short-maturity debt gives managers fewer opportunities to withhold adverse information, which in turn facilitates the reflection of such information in stock prices on a more timely and regular basis. To the extent that bad news hoarding leads to higher

\footnotetext{
${ }^{4}$ In addition to short-term lenders, other debt market participants such as investors, underwriters, rating agencies, and analysts may also exercise their monitoring function (Datta et al., 2005), thus helping to promptly reflect corporate information in stock prices.
} 
stock price crash risk (e.g., Jin and Myers, 2006; Hutton et al., 2009; Callen and Fang, 2015b; and Kim and Zhang, 2016), the decrease in bad-news-hoarding opportunities induced by short-term debt should reduce extreme downward price corrections upon sudden revelation of the previously accumulated and concealed negative information. Hence, we formulate our first hypothesis as follows:

H1: Firms with a higher proportion of short-term debt are associated with lower future stock price crash risk.

If the negative relation between short-term debt and crash risk is indeed attributed to the monitoring role of short-term debt in reducing bad news hoarding by opportunistic and self-serving managers, then we expect this relation to be more pronounced among firms likely to be associated with greater agency or information problems, such as those with weaker governance, higher information asymmetry, and excessive risk-taking (Kim et al., 2011a; Callen and Fang, 2015b; Andreou et al., 2016). The rationale for this prediction is that the monitoring function of short-term debt is most effective at enhancing information disclosure among firms in which managers are poorly disciplined, harder to monitor, and allowed greater discretion. In firms with weaker governance monitoring mechanisms, managers would be less accountable for not releasing information on a timely basis (Bhojraj and Sengupta, 2003) or for not providing high-quality information (Bae et al., 2006). Meanwhile, in firms with lower corporate transparency, investors are less able to monitor managerial performance (Bushman and Smith, 2001) and are more likely to misprice securities (Lee et al., 2014). Furthermore, managers of riskier firms are both more difficult to monitor (Demsetz and Lehn, 1985) and more likely to conceal unfavorable news to avoid being perceived by investors as taking on excessive risk (Callen and Fang, 2015b). Overall, to the extent that short-term debt lenders effectively serve as a substitute for alternative monitoring mechanisms that are lacking in those firms, short-term debt should exert a more pronounced impact to curb managers' bad-news-hoarding activities and contribute to the reduction of future crash risk. These arguments lead to three further hypotheses:

H2: The relation between short-term debt and future stock price crash risk is stronger for firms with weaker governance. 
H3: The relation between short-term debt and future stock price crash risk is stronger for firms with a higher degree of information asymmetry.

H4: The relation between short-term debt and future stock price crash risk is stronger for firms with greater risk-taking.

\section{Research Design}

\subsection{Data and Sample}

We measure U.S. firms' crash risk using stock return data from the Center for Research in Security Prices (CRSP) from 1989 through 2014. We collect firm accounting and financial data from Compustat annual files. Our sample period starts in 1989 because our explanatory variables (lagged by one year) are computed from 1988, the first year for which we can estimate discretionary accruals using the cash flow statement method. Following previous research (e.g., Hutton et al., 2009), we exclude firms (i) with year-end share prices below $\$ 1$, (ii) with fewer than 26 weeks of stock return data in each fiscal year, (iii) with negative total assets and book values of equity, (iv) operating in financial (SIC codes 6000-6999) or public utility (SIC codes 4900-4999) industries, and (v) with insufficient data to calculate the variables used in our regressions. Our final sample consists of 7,712 firms and 53,052 firm-year observations.

\subsection{Measuring Short-maturity Debt}

Following prior studies on debt maturity (e.g., Johnson, 2003; Datta et al., 2005; Brockman et al., 2010; Harford et al., 2014), our main proxy for short-maturity debt is the proportion of total debt maturing in three years or less, ST3. In our robustness tests, we consider alternative measures of shortterm debt, namely, the fraction of debt maturing within one (ST1), two (ST2), and five years (ST5), as well as the ratio of short-term debt to total assets $\left(S T_{-} T A\right)$. We also use a new measure of very short-term debt, that is, short-term debt due within one year net of the current proportion of long-term debt that is maturing $(S T N P 1)$. In addition, in further analysis using a sample of new debt issues, we measure debt maturity as the maturities of new bond or loan issues, in logarithmic form. 


\subsection{Measuring Stock Price Crash Risk}

Stock price crash risk reflects the tendency of extreme negative returns on individual firms. We follow Jin and Myers (2006) and compute alternative measures of crash risk using firm-specific weekly returns. Based on Hutton et al. (2009), we first estimate the following expanded market model to compute those weekly returns:

$$
r_{j, \tau}=\alpha_{j}+\beta_{1, j} r_{m, \tau-1}+\beta_{2, j} r_{i, \tau-1}+\beta_{3, j} r_{m, \tau}+\beta_{4, j} r_{i, \tau}+\beta_{5, j} r_{m, \tau+1}+\beta_{6, j} r_{i, \tau+1}+\varepsilon_{j, \tau}
$$

where $r_{j, \tau}$ is the return on stock $j$ in week $\tau, r_{m, \tau}$ is the return on CRSP value-weighted market index, and $r_{i, \tau}$ is the Fama and French value-weighted industry index in week $\tau$. Following Dimson (1979), we include the lead and lag terms to correct for nonsynchronous trading. The firm-specific return for stock $j$ in week $\tau$ $\left(W_{j, \tau}\right)$ is measured by the natural logarithm of one plus the residual return from Eq. (1). ${ }^{5}$

As in Chen et al. (2001) and Kim et al. (2011a, 2011b), our first crash risk measure is the negative conditional skewness of firm-specific weekly returns (NCSKEW). We calculate NCSKEW for firm $j$ over fiscal year $t$ by taking the negative of the third moment of firm-specific weekly returns for each year and dividing it by the standard deviation of firm-specific weekly returns raised to the third power. A stock with high $N C S K E W$ represents a highly left-skewed return distribution and a high probability of a price crash. The formula for the negative conditional skewness for firm $j$ in year $t$ is as follows:

$$
N \operatorname{CSKEW} W_{j, t}=-\left[n(n-1)^{3 / 2} \sum W_{j, \tau}^{3}\right] /\left[(n-1)(n-2)\left(\sum W_{j, \tau}^{2}\right)^{3 / 2}\right]
$$

where $W_{j, \tau}$ is the firm-specific weekly return as defined above and $n$ is the number of weekly returns in fiscal year $t$.

Our second measure of firm-specific crash risk is "down-to-up volatility," which is calculated as follows:

\footnotetext{
${ }_{5}^{5}$ Jin and Myers (2006) and Kim et al. (2011a, 2011b) estimate firm-specific weekly returns using an alternative market model that does not include the industry index. In untabulated robustness checks, we employ this model to recalculate our crash risk measures and obtain qualitatively similar results.
} 


$$
\operatorname{DUVOL}_{j, t}=\log \left\{\left(n_{u}-1\right) \sum_{D o w n} W_{j, \tau}^{2} /\left(n_{d}-1\right) \sum_{U p} W_{j, \tau}^{2}\right\}
$$

where $n_{u}$ and $n_{d}$ are the number of up and down days over the fiscal year $t$, respectively. For each firm $j$ over year $t$, we separate firm-specific weekly returns into down (up) weeks when the weekly returns are below (above) the annual mean. We separately calculate the standard deviation of firm-specific weekly returns for each of the two groups. Then, $D U V O L$ is the natural logarithm of the ratio of the standard deviation in the down weeks to the standard deviation in the up weeks. Chen et al. (2001) suggest that a high $D U V O L$ indicates a more left-skewed distribution. We note that $D U V O L$ is less likely to be affected by the number of extreme returns as it does not involve third moments.

\subsection{Control Variables}

Following prior studies of stock price crash risk (e.g., Chen et al., 2001; Jin and Myers, 2006), we employ the following set of control variables: stock turnover $(D T U R N)$, stock return volatility $(S I G M A)$, firm size $(S I Z E)$, market-to-book ratio $(M B)$, leverage $(L E V)$, return on assets $(R O A)$, lagged negative conditional skewness $(N C S K E W)$, and earnings quality $(A C C M)$. The control variables are all lagged one period and measured as follows: $D T U R N_{t-1}$ is the difference between the average monthly share turnover over fiscal year $t-1$ and $t-2$. SIGMA $A_{t-1}$ is the standard deviation of firm-specific weekly returns in fiscal year $t-1 . R E T_{t-1}$ is the average firm-specific weekly returns in fiscal year $t-1 . S I Z E_{t-1}$ is the $\log$ of the market value of equity in year $t-1 . M B_{t-1}$ is the market value of equity divided by the book value of equity in year $t-1 . L E V_{t-1}$ is the book value of total liabilities scaled by total assets in fiscal year $t-1 . R O A_{t-1}$ is income before extraordinary items divided by total assets at the end of fiscal year $t-1$. NCSKE $W_{t-1}$ is the negative conditional skewness for firm-specific weekly returns in fiscal year $t-1 . A C C M_{t-1}$ is defined as the absolute value of discretionary accruals, where discretionary accruals are the residuals estimated from the modified Jones model (Hutton et al., 2009). Finally, we control for Fama and French 48-industry and 
year effects. ${ }^{6}$ To mitigate the influence of outliers, we winsorize all the continuous variables at the $1 \%$ and 99\% levels. We provide detailed variable definitions in the Appendix.

\section{Empirical Results}

\subsection{Descriptive Statistics}

Table 1 presents the descriptive statistics for all the variables used in our regressions. The mean values of two stock price crash risk measures, NCSKEW and DUVOL, are -0.085 and -0.055 , respectively, which are quite similar to those reported in Kim et al. (2011b). Short-term debt, ST3, has a mean value of 0.541 , which is in line with the reported means in Johnson (2003) and Custódio et al. (2013). ${ }^{7}$ The summary statistics of the other variables are largely consistent with those reported in prior research, and thus are not discussed herein to preserve space.

Moreover, in untabulated correlation analysis, the two crash risk measures, NCSKEW and DUVOL, are significantly and negatively correlated with short-maturity debt, ST3; their correlation coefficients are -0.059 and -0.064 , respectively. This finding lends initial support to our prediction that short-term debt induces a lower probability of future stock price crashes. Consistent with prior research, we find the two crash risk measures to be positively correlated with each other, with a very high correlation coefficient of 0.961 .

\section{[Insert Table 1 about here]}

\subsection{Baseline Regression Results}

We examine the impact of short-term debt on future stock price crash risk by estimating the following regression model:

$$
\begin{gathered}
\operatorname{Crash~Risk}_{j, t}=\beta_{0}+\beta_{1} \operatorname{ST}_{j, t-1}+\beta_{2} \operatorname{DTURN}_{j, t-1}+\beta_{3} \operatorname{SIGMA}_{j, t-1}+\beta_{4} \operatorname{RET}_{j, t-1}+\beta_{5} \operatorname{SIZE}_{j, t-1}+ \\
\beta_{6} M B_{j, t-1}+\beta_{7} \operatorname{LEV}_{j, t-1}+\beta_{8} \text { ROA }_{j, t-1}+\beta_{9} \operatorname{NCSKEW}_{j, t-1}+\beta_{10} \text { ACCM }_{j, t-1}+\varepsilon_{j, t}
\end{gathered}
$$

\footnotetext{
${ }^{6}$ Our results are robust to controlling for industry fixed effects defined by 2-digit or 4-digit SIC codes.

${ }^{7}$ Custódio et al.'s (2013) measure of debt maturity is the fraction of debt maturing after 3 years, that is, $1-$ ST3.
} 
Table 2 presents the regression results for this model. In Columns (1) and (4), we regress two crash risk measures, $N C S K E W$ and $D U V O L$, on short-maturity debt, ST3, and the control variables. In Columns (2) and (5), we include year fixed effects to control for a secular increase in short-term debt (Custódio et al., 2013). We further control for both year and industry fixed effects in Columns (3) and (6). The results across the table show that short-term debt is significantly and negatively associated with oneyear ahead stock price crash risk. For example, in our preferred baseline models in Columns (3) and (6), the coefficients on ST3 are $-0.048(t$-stat $=-4.30)$ and $-0.023(t$-stat $=-4.57)$, respectively. This finding suggests that firms with more short-term debt experience lower future stock price crash risk, consistent with the notion that the monitoring of short-maturity debt restricts managers from hiding bad news, thus leading to a lower likelihood of firms' future stock price crashes.

We further evaluate the economic significance of the effect of short-maturity debt on future crash risk. Following Hutton et al. (2009), we compare the values of cash risk corresponding to the $25^{\text {th }}$ and $75^{\text {th }}$ percentile values of short-term debt $(0.217$ and 0.938 , respectively), while keeping all other control variables at their sample means. In Columns (3) and (6), we find that the decrease in NCSKEW (DUVOL) is $0.035(0.017)$ or $40.72 \%(30.15 \%)$ relative to the sample mean, when there is an increase from the $25^{\text {th }}$ to $75^{\text {th }}$ percentiles of the distribution of short-maturity debt. Moreover, the economic impact of short-term debt is twice as large as the impact of earnings quality $(A C C M)$ on crash risk $(17.12 \%$ and $7.75 \%$, respectively, for $N C S K E W$ and $D U V O L$ ). These results suggest that the effect of short-maturity debt on crash risk not only is statistically significant but also has large economic significance. We thus conclude that our baseline regression results provide strong support for Hypothesis HI.

The results regarding the control variables are generally consistent with prior studies. The coefficients on stock turnover (DTURN) and stock return volatility (SIGMA) are significant and positive, which is consistent with Chen et al.'s (2001) finding that stocks with higher turnover and higher return volatility are likely to experience more price crashes in the future. The coefficients on past returns (RET) and market-to-book ratio $(M B)$ are also significantly positive, in line with Harvey and Siddique (2000) and Chen et al. (2001). To the extent that high stock returns and high market-to-book signal the buildup of 
a stock price bubble, these variables are likely to be associated with higher future crash risk. The coefficient on leverage $(L E V)$ is negative, which seems to reflect firms' endogenous capital structure choice as less crash-prone firms may have stronger incentives to accumulate debt (Hutton et al., 2009; Kim et al., 2011b). Moreover, the coefficients on firm size (SIZE), lagged crash risk (NCSKEW), and earnings quality $(A C C M)$ are positive, which is consistent with the evidence documented in prior studies (e.g., Chen et al., 2001; Hutton et al., 2009). Finally, we find a positive association between profitability (ROA) and crash risk, corroborating the findings of Kim et al. (2014) and Callen and Fang (2015b).

[Insert Table 2 about here]

\subsection{Identification Strategies and Robustness Checks}

\subsubsection{Dealing with Endogeneity}

One major concern about the baseline results reported in Table 2 is that the debt maturity structure may be endogenous, in which case the estimated negative effect of short-term debt on crash risk would be biased and inconsistent, and our inference thus far would be invalid. One main source of this endogeneity is the potential presence of omitted variables as short-term debt may be correlated with unobserved firm-specific characteristics that affect future crash risk. Another common source of endogeneity includes reverse causality and simultaneity since crash risk may explain variation in shortterm debt or that the two variables may be jointly determined. ${ }^{8}$ To address these potential endogeneity problems, we employ several estimation approaches.

First, we run firm fixed-effects (FE) and first-differences (FD) regressions to control for timeinvariant unobserved firm characteristics and alleviate the potential omitted-variable bias due to heterogeneity. The FD regression further addresses the concern that our main measure of short-maturity debt may reflect past debt maturity decisions as it includes the proportion of long-term debt that is

\footnotetext{
${ }^{8}$ We note this endogeneity concern is less likely to affect our results because we examine the impact of current short-term debt on future stock price crash risk. Given that short-term debt evolves over time (Custódio et al., 2013), it is unlikely that future crash risk affects current short-term debt.
} 
maturing. By estimating this model, we can better capture how a change in debt maturity structure affects a change in the likelihood of future stock price crashes. In Panel A of Table 3, the results from the FE and FD regressions show that the relation between short-term debt and future stock price crash risk remains negative and significant for both crash risk measures. This suggests that our main findings continue to hold after controlling for unobserved heterogeneity.

Our second strategy to address endogeneity involves using the dynamic system generalized method of moments (SYSGMM) approach (Blundell and Bond, 1998), which takes into account the dynamics of stock price crash risk, while accounting for other sources of endogeneity in the model (e.g., Kim et al., 2014). We employ the SYSGMM estimator because our estimated model of stock price crash risk is a dynamic panel data model that includes lagged crash risk as a regressor $\left(N C S K E W_{t-1}\right)$. Using the traditional ordinary least squares (OLS) method for estimating the model might lead to biased and inconsistent estimates of the coefficients because the dynamic term, lagged crash risk, may be correlated with unobservable firm-specific factors and this potential correlation would not be eliminated in the FE and FD regressions (Baltagi, 2013). In applying the SYSGMM, we estimate Eq. (4) in both levels and first-differences using appropriate instruments for the two endogenous variables, crash risk (NCSKEW $\left.W_{t-1}\right)$ and short-term debt $\left(S T 3_{t-1}\right)$. In the levels equations, our instruments for $N C S K E W_{t-1}$ and $S T 3_{t-1}$ include their lagged values in first differences. In the first-differenced equations, our instruments for $\triangle N C S K E W_{t-1}$ and $\triangle S T 3_{t-1}$ are the lagged values of $N C S K E W_{t-1}$ and $S T 3_{t-1}$, both in levels. ${ }^{9}$

Panel B of Table 3 reports the results from our SYSGMM regressions. We find that the coefficient on short-term debt is significantly negative in both models, consistent with the baseline results. In terms of diagnostic tests, the second-order autocorrelation $(A R 2)$ and $J$-tests provide no evidence of

\footnotetext{
${ }^{9}$ Specifically, in the levels equations, we use $\triangle N C S K E W_{t-2}, \triangle N C S K E W_{t-3}, \ldots, \triangle N C S K E W_{1}$ as instruments for $N C S K E W_{t-1}$. In the first-differenced equations, we use $N C S K E W_{t-2}, N C S K E W_{t-3}, \ldots, N C S K E W_{1}$ as instruments for $\triangle N C S K E W_{t-1}$. We construct the instrument matrix for $S T 3_{t-1}$ in a similar way.
} 
second-order autocorrelation and over-identification. This suggests that our instruments are valid and that the specifications we use are appropriate.

In unreported analyses, we perform two additional tests to further address the endogeneity concern. ${ }^{10}$ First, we employ the instrumental variable (IV) approach, in which we use the term structure of interest rates (TERMSTR) as an instrument for short-maturity debt; TERMSTR is measured as the difference between the yield on 10-year government bonds and the yield on 6-month Treasury bills. We argue that this instrument plausibly satisfies both the relevance and exclusion conditions of a valid IV. First, prior empirical studies provide evidence of a significant and positive relation between term structure and short-maturity debt (e.g., Barclay and Smith, 1995; Johnson, 2003; Brockman et al., 2010). For example, these studies suggest that firms prefer short-maturity debt to long-maturity debt because the former source of debt financing is typically less costly, unless the yield curve is inverted. Second, regarding the exclusion condition, term structure and stock price crash risk are not likely to be correlated, unless via the debt maturity channel. This is because that the changing pattern of the yield curve is unlikely to affect managers' bad-news-hoarding activities directly. Our IV regression results (untabulated) show that short-term debt remains significantly and negatively related to both measures of future stock price crash risk.

Second, we further mitigate the omitted-variable bias, a major source of the endogeneity concern, by controlling for the following set of variables that may affect future crash risk but are potentially related to debt maturity choice: (i) firm quality, measured as abnormal earnings (Custódio et al., 2013); (ii) credit quality, measured as bond rating (Diamond, 1991a); and (iii) the degree of financial constraint, proxied by the dividend payout ratio (Faulkender and Wang, 2006), the Kaplan and Zingales (1997) index, the Whited and Wu (2006) index, and the Hadlock and Pierce (2010) Size-Age index. We control for firm quality and credit quality because high-quality firms are less likely to experience future price crashes, while, under asymmetric information, they are more likely to issue short-term debt as a signal of good

\footnotetext{
${ }^{10}$ The results are untabulated for brevity, but available upon request.
} 
future prospects (Flannery, 1986; Ozkan, 2000). We include the degree of financial constraint since constrained firms tend to rely more on short-maturity debt as they are likely to be screened out of the long end of the maturity spectrum (Diamond, 1991a). Meanwhile, these firms may use discretionary accruals opportunistically to attract external financing (Dechow et al., 1996; Dechow et al., 2011); their aggressive earnings management could, in turn, result in higher synchronicity risk and future stock price crash risk (Hutton et al., 2009). The (unreported) results show that the coefficient on short-term debt is significantly negative, whether we include the additional control variables in our models separately or together, or measure crash risk using NCSKEW or DUVOL.

In summary, the results from the above tests show that, controlling for heterogeneity and endogeneity, short-term debt exerts a negative impact on future stock price crash risk. This finding is consistent with our baseline results and provides further support for Hypothesis H1.

[Insert Table 3 about here]

\subsubsection{Other Robustness Checks}

We perform a series of robustness checks using alternative measures of our key variables and controlling for a set of fundamental risk variables that may also affect future stock price crash risk. Following prior research on debt maturity (e.g., Barclay and Smith, 1995), we additionally measure shortterm debt as the proportion of total debt maturing within one (ST1), two (ST2), or five years (ST5). We further use an alternative measure of short-term debt maturing within three years $\left(S T 3_{-} T A\right)$ by scaling it using total assets, rather than total debt as in our main analysis. Following Huang et al. (2016), we consider a new measure of very short-term debt (STNP1), which we define as the ratio of debt in current liabilities net of long-term debt due in one year, scaled by total debt. By using STNP1, we can rule out the effect of the long-term debt that is maturing. Panel A of Table 4 reports the results for five alternative 
measures of short-term debt. We find that the coefficients on those measures, namely, ST1, ST2, ST5, ST3_TA, and STNP1, are all significant and negative for both crash risk measures. ${ }^{11}$

Following Jin and Myers (2006) and Callen and Fang (2015b), we further measure stock price crash risk as the number of crashes minus the number of jumps over the fiscal year (COUNT). Specifically, we first define crash weeks in a given fiscal year as those during which a firm experiences firm-specific weekly returns 3.09 standard deviations below the mean firm-specific weekly returns over the whole fiscal year, with 3.09 chosen to generate a frequency of $0.1 \%$ in the normal distribution. Likewise, when the firm-specific weekly return is 3.09 standard deviations above its mean in a fiscal year, we define those weeks as jump weeks. As in Hutton et al. (2009), Kim et al. (2011b), and Chang et al. (2016), we also measure future stock price crash risk as the likelihood that a firm experiences more than one price crash week in a fiscal year $(C R A S H)$. The results in Panel $\mathrm{B}$ of Table 4 show that all six alternative measures of short-term debt are significantly and negatively related to COUNT. Furthermore, short-term debt has a negative impact on $C R A S H$, although this impact is only significant for four measures of short-term debt. In further (untabulated) robustness checks, we find that our main results continue to hold when we use two- or three-year-ahead crash risk measures.

In the main analysis, we measure leverage as the ratio of total debt to total assets, which is one of the most conventional measures used in prior capital structure studies (e.g., Graham et al., 2015; Öztekin, 2015), including those that examine both debt maturity and leverage in a single model specification as we do in this paper (e.g., Billet et al., 2007). However, since total debt includes short-maturity debt, one possible concern is that the coefficient on short-term debt may not clearly identify the effect of shortmaturity debt on crash risk. To mitigate this concern, we use an alternative measure of leverage, which is calculated as long-term debt divided by total assets. As can be seen in Panel C of Table 4, the coefficients on short-term debt remain positive and statistically significant for our main crash risk measures.

\footnotetext{
${ }^{11}$ In unreported results, we further measure short-term debt using the ratio of short-maturity loans (loans that have a time-to-maturity of less than three years) to total loans. Our main inferences remain qualitatively the same.
} 
Finally, to ensure that our findings are not driven by fundamental risk factors, we replicate our main analysis by further controlling for a set of variables that capture risk, including earnings volatility (the standard deviation of the ratio of earnings, excluding extraordinary items and discontinued operations, to lagged total equity during the past five years), cash flow volatility (the standard deviation of the ratio of cash flow to total assets in the past five years), sales volatility (the standard deviation of the ratio of sales to total assets in the past five years), ${ }^{12}$ and beta (the covariance between the individual firm return and the market return divided by the variance of the market return over a fiscal year). In Panel D of Table 4, the coefficients on short-term debt are significantly negative after including these additional controls. Overall, we conclude that our main findings are generally robust to the use of alternative measures of future stock price crash risk, short-maturity debt, and leverage, as well as the inclusion of various risk factors.

\section{[Insert Table 4 about here]}

\subsubsection{New Debt Issues}

Although our approach of calculating short-maturity debt based on the balance sheet data is widely used in the literature, as mentioned, one concern about this approach is that the short-term debt ratio may be affected by the proportion of long-term debt that is coming due. This fraction of maturing long-maturity debt is unlikely to have the desired monitoring effect on managers' bad-news-holding behavior as our hypothesis predicts. We note that in two robustness checks above, we have, to an extent, addressed this concern by (i) running a change (FD) regression and (ii) focusing on short-term debt due within one year, net of the current proportion of maturing long-term debt, STNP1. In this section, we follow prior research (e.g., Guedes and Opler, 1996; Brockman et al., 2010; Custódio et al., 2013) and further use an incremental approach in which we focus on newly issued debt. This incremental approach better captures the relations between debt maturity structure and firm-specific variables at all points of the

\footnotetext{
${ }^{12}$ Our findings are unaffected if the volatility measures (i.e., earnings, cash flow, and sales volatility) are calculated using data in the past three years.
} 
maturity spectrum (Guedes and Opler, 1996). Importantly, it also allows us to better study the causal effect of the maturities of new debt issues on one-year-ahead crash risk, while avoiding potential endogeneity problems due to reverse causality and simultaneity.

Following Custódio et al. (2013), we obtain data on both bond issues and private bank loan issues. Data on new bonds are from the Mergent Fixed Income Securities Database (FISD) and data on new loans come from the Loan Pricing Corporation's Dealscan database, which contains issuance-level information on syndicated bank loans. We first construct a transaction-level (unconsolidated) sample of new debt issues, including both bonds and loans. Merging data of new debt issues with Compustat leaves us with an unconsolidated sample of 4,233 unique firms and 32,785 debt issues. We measure the debt maturity of a debt issue (DEBT_MAT) as the natural logarithm of the maturity of the issue.

As robustness checks, we examine different samples of debt issues. First, we construct an unconsolidated sample using data on newly issued private bank loans only. Our sample of loan issues consists of 24,845 transactions. Second, following Brockman et al. (2010), we further construct a consolidated (firm-level) sample of both bond and loan issues to deal with the possibility that firms have multiple debt issues within a fiscal year. We measure the debt maturity of those multiple issues as the natural logarithm of the issue-size-weighted maturity (WAVG_MAT). ${ }^{13}$ Our (firm-level) consolidated sample consists of 16,685 firm-year observations.

Table 5 presents the regression results for both the unconsolidated and consolidated samples. In the first two columns of Panel A, the coefficient on debt maturity $\left(D E B T_{-} M A T\right)$ is significantly positive for both NCSKEW and DUVOL. This finding continues to hold after we control for the size of new debt issues (DEBT_SIZE). Taken together, our results indicate that firms that issue debt with longer (shorter) maturity are more (less) likely to experience future stock price crashes, which is also in line with our prediction. Panel B shows the effect of the maturities of new loan issues on future stock price crash risk. The coefficient on loan maturity $\left(L O A N_{-} M A T\right)$ is positive and significant, whether we control for the

\footnotetext{
${ }^{13}$ The results (untabulated) are robust if we use the natural logarithm of the equal-weighted maturity.
} 
amount of the loan issue ( $\left.L O A N \_S I Z E\right)$ or not. Its magnitude seems higher than the magnitude of the coefficient on debt maturity in Panel A, which is consistent with our expectation. Panel C presents the results for the consolidated sample of new debt issues. In the last two columns of the panel, we further control for the total amount of firms' multiple debt issues within a fiscal year (SUM_SIZE). The results show that the coefficients on $W A V G_{-} M A T$ are positive and significant, for both crash risk measures, NCSKEW and DUVOL. Overall, the evidence from different samples of new debt issues is consistent with our baseline regression results obtained using the balance sheet data and provides additional support for Hypothesis H1.

\section{[Insert Table 5 about here]}

\subsection{Corporate Governance Mechanisms and Short-maturity Debt}

We next examine whether the negative relationship between short-term debt and future stock price crash risk is attenuated by the strength of firms' governance monitoring mechanisms, as predicted by Hypothesis H2. We employ three proxies for the effectiveness of corporate governance, namely, the proportion of total institutional ownership (INST), the proportion of long-term-oriented institutional ownership (LTINST), and the governance index (GINDEX). The former two variables measure the monitoring power of institutional investors, while the latter proxies for monitoring by equity markets. Using data from Thomson 13F, we calculate the proportion of total institutional ownership (INST) as the percentage of shares held by institutional owners. We further compute the proportion of long-term (nontransient) institutional ownership (LTINST) as the percentage of common shares owned by dedicated and quasi-indexer institutions. ${ }^{14}$ We focus on dedicated investors because prior research finds that they play an important monitoring role in curbing managerial myopic behavior (e.g., Bushee, 1998, 2001). We further include quasi-indexers because recent evidence suggests that these investors are not passive owners as they hold sway over managers and typically demand greater firm transparency and public information

\footnotetext{
${ }^{14}$ We follow Bushee $(1998,2001)$ and categorize institutional investors into quasi-indexers, transient, or dedicated based on their portfolio turnover, diversification, and expected investment horizon.
} 
production (e.g., Boone and White, 2015; Appel et al., 2016). We exclude transient investors from our calculation of LTINST because these investors have shorter term horizons and hence fewer incentives to understand and monitor firms (e.g., Andreou et al., 2016; Chang et al., 2016). Regarding the governance index (GINDEX), we collect the data on this variable from the RiskMetrics database. GINDEX measures the strength of antitakeover provisions (Gompers et al., 2003); firms with fewer antitakeover provisions have better shareholder rights protection and lower managerial discretion.

We partition the full sample into subsamples based on the annual median values of the governance measures and report the results in Table 6. In Panels A and B, we divide the sample into firms with strong (weak) external institutional monitoring, defined as those with above-median (below-median) INST and LTINST, respectively. In both panels, we find that the effect of short-term debt on crash risk is always negative, but only significant, at least at the 5\% level, when (long-term-oriented) institutional shareholdings are lower. This finding holds for both measures of crash risk, NCSKEW and DUVOL. In Panel C, we define weak (strong) governance firms as those with above- (below-) median GINDEX. The results show that the coefficient on short-term debt is negative for both groups of firms, but significant at the $1 \%$ level for those with weaker governance (Columns (1) and (3)) while insignificant for those with stronger governance (Columns (2) and (4)).

To compare the differences between the coefficients on short-maturity debt (ST3) across the subsamples, we also follow the approach in Kim et al. (2011b) and Callen and Fang (2015b) and estimate an alternative specification in which we include an interaction term between $S T 3$ and each governance measure defined above. Our specification is similar to Eq. (4) for the whole sample, with two additional regressors being the interaction term and the governance measure of interest. The results (untabulated) suggest that the coefficient on the interaction term $S T 3 \times I N S T$ is significantly negative for both measures of crash risk, NCSKEW and DUVOL. This finding is consistent with the above evidence that institutional ownership moderates the negative impact of short-maturity debt on future crash risk. We obtain qualitatively similar results regarding the interaction term between ST3 and either LTINST or GINDEX, although $S T 3 \times$ GINDEX becomes less significant. 
Overall, our results support Hypothesis $H 2$ that the negative effect of short-term debt on crash risk is more pronounced among firms with weak corporate governance mechanisms, consistent with short-term debt serving as an effective monitoring tool to reduce managers' bad-news-hoarding activities when the monitoring by institutional investors and shareholders is insufficient. Our evidence is also in line with prior studies on stock price crash risk. For example, Kim et al. (2011b) find that effective external monitoring can moderate the positive impact of tax avoidance on crash risk, while Callen and Fang (2015b) show that the negative relation between religion and crash risk becomes weaker among firms with strong governance mechanisms.

[Insert Table 6 about here]

\subsection{Information Asymmetry and Short-maturity Debt}

We next study whether the relation between short-term debt and future stock price crash risk is more pronounced among firms with a weak information environment, as predicted by Hypothesis H3. Following prior research, we measure the degree of information asymmetry using analyst forecast error (FERR) (Callen and Fang, 2015a), analyst forecast dispersion (DISPER), and R\&D intensity (RD) (Custódio et al., 2013). We obtain analyst earnings forecast data from the $\mathrm{I} / \mathrm{B} / \mathrm{E} / \mathrm{S}$ database. We define analyst forecast error $(F E R R)$ as the absolute value of the difference between actual earnings per share and the consensus analyst forecast, divided by the consensus analyst forecast. The dispersion of analyst forecasts $(D I S P E R)$ is the standard deviation of analyst forecasts divided by the consensus analyst forecasts. $\mathrm{R} \& \mathrm{D}$ intensity $(R D)$ is the ratio of research and development expenditure to total assets. We expect higher analyst forecast error, higher forecast dispersion, and greater R\&D intensity to be associated with higher levels of information asymmetry (e.g., Healy and Palepu, 2001; Zhang, 2006; and Custódio et al., 2013).

In Table 7, we split the sample into firms with high and low levels of asymmetric information based on those three measures. The results in Panel A show that the coefficient on short-term debt is significantly negative at the $1 \%$ level for the subsample of firms with high analyst forecast error. 
However, for firms with low analyst forecast error, the coefficient is insignificant or only marginally significant at the $10 \%$ level. Similarly, in Panel B, the coefficient on short-term debt is significantly negative for firms with greater dispersions in analysts' forecasts, but either insignificantly or marginally negative for those with lower dispersions. Panel $\mathrm{C}$ also reveals that the coefficient on short-term debt is statistically significant only for R\&D-intensive firms.

As a robustness check, we interact short-term debt with each measure of information asymmetry defined above and add both this interaction term and the information asymmetry measure in question to the baseline model (Eq. (4)). As mentioned above, this interaction term approach enables us to test for differences in the estimated coefficients on short-maturity debt (ST3) across the subsamples in Table 7. The results (untabulated) show that the coefficient on the interaction term ST3 $\times$ FERR is negative and significant, consistent with short-maturity debt exerting a stronger mitigating effect on crash risk when firms have weaker analyst monitoring and a higher degree of information asymmetry. We obtain qualitatively similar results when we repeat this analysis and include the interaction term between ST3 and either DISPER or $R D$; the interaction term ST3 $\times$ DISPER is significantly negative, while the interaction term $S T 3 \times R D$ is negative but insignificant.

Overall, our findings are broadly consistent with Hypothesis $H 3$ that the role of short-term debt in mitigating managers' information withholding and lowering future stock price crash risk is stronger when there is less corporate transparency.

[Insert Table 7 about here]

\subsection{Risk-taking and Short-maturity Debt}

Finally, we investigate whether the relationship between a firm's short-maturity debt and future stock price crash risk is conditional on its riskiness, as predicted by Hypothesis H4. We follow Johnson (2003) and use two proxies for the riskiness of the firm, including leverage (LEV) and bond rating status (RATEDUM). We classify a firm as being risker if its leverage is above the sample median or if it does not have a bond rating. 
In Panels $\mathrm{A}$ and $\mathrm{B}$ of Table 8, we partition the sample into firms with high and low risk-taking based on their leverage ratios and rating status, respectively. In Panel A, the coefficient on short-maturity debt is significantly negative at the $1 \%$ level for the riskier firms but insignificant for the less risky counterparts. Furthermore, the coefficients on short-term debt are much larger in magnitude for the riskier subsample. The results in Panel B show that the coefficient on short-term debt is negative and significant at least at the 5\% level among the unrated group, while it is only marginally significant among the rated group.

To further test for differences in the coefficients on short-maturity debt (ST3) across the subsamples in Table 8, we adopt the interaction term approach as mentioned above, that is, we add an interaction term between ST3 with each measure of riskiness to our baseline model (Eq. (4)). The results (untabulated) reveal that the coefficient on the interaction term $S T 3 \times L E V$ is negative and significant, again supporting our prediction that short-maturity debt has a more pronounced effect on future crash risk among highly leveraged firms. The results are qualitatively similar when we add the interaction term between $S T 3$ and RATEDUM to our baseline model (i.e., we find $S T 3 \times R A T E D U M$ to be significantly negative).

Overall, the results in Table 8 are consistent with our Hypothesis $H 4$ that the influence of shortmaturity debt on future crash risk is stronger among firms with a higher level of risk-taking. Our evidence is also in line with the recent finding by Callen and Fang (2015b) that the impact of religiosity on future crash risk is more concentrated in riskier firms.

[Insert Table 8 about here]

\section{Conclusion}

This study examines the impact of debt maturity on stock price crash risk. We provide original evidence of a negative relationship between the use of short-term debt and the likelihood of subsequent stock price crashes. The results are robust to a battery of robustness checks, including tests addressing endogeneity concerns, using alternative measures of debt maturity and crash risk, and focusing on various 
samples of new debt issues. Our findings are consistent with the monitoring role of short-term debt serving as an effective tool to curb managerial bad-news-hoarding behavior, which in turn reduces stock price crash risk.

We also investigate whether the influence of short-term debt on crash risk is conditional on corporate governance mechanisms, information asymmetry, and firm riskiness. Our findings indicate that the mitigating effect of short-term debt on future crash risk is more pronounced when firms have lower shareholder rights and less (non-transient) institutional ownership. Furthermore, the negative relationship between short-maturity debt and future crash risk is stronger among firms with weaker analyst monitoring and higher asymmetric information and among riskier firms with high leverage and without credit rating. Taken together, these results highlight the importance of short-term debt for firms with weaker governance, a weaker information environment, or greater riskiness. Put differently, short-term debt may act as a substitute for corporate governance mechanisms in reducing managerial bad news hoarding and future stock price crash risk.

Overall, our study complements a growing body of research on stock price crash risk and debt maturity structure. In the crash risk literature, we provide the first novel evidence that a corporate financial policy such as debt maturity has a significant influence on high moments of stock return distribution, above and beyond the effects of other determinants of crash risk identified by prior studies. In the debt maturity literature, we show that firms can benefit from short-term debt due to its mitigating effect on future stock price crash risk, supporting the notion that "short-term debt maturity can be an extremely powerful tool to monitor management" (Stulz, 2001, p. 172). Together, these add to a greater understanding of how debt financing can contribute to improving corporate governance and reducing agency costs. Our study suggests that short-maturity debt enables creditors to constrain managers' misconduct, which in turn is mutually beneficial to shareholders' wealth through the reduction of stock price crash risk. Finally, our findings provide relevant implications for equity investors who wish to predict and avoid future stock price crash risk based on information about debt maturity policy. 


\section{References}

Aivazian, V., Ge, Y. and Qiu, J., 'Debt maturity structure and firm investment', Financial Management, Vol. 34(4), 2005, pp. 107-119.

Almeida, H., Campello, M., Laranjeira, B. and Weisbenner, S., 'Corporate debt maturity and the real effects of the 2007 credit crisis', Critical Financial Review, Vol. 1(1), 2011, pp. 3-58.

An, H. and Zhang, T., 'Stock price synchronicity, crash risk, and institutional investors', Journal of Corporate Finance, Vol. 21, 2013, pp. 1-15.

Andreou, P. C., Antoniou, C., Horton, J. and Louca, C., 'Corporate governance and firm-specific stock price crashes', European Financial Management, 2016, forthcoming.

Antoniou, A., Guney, Y. and Paudyal, K., 'The determinants of corporate debt maturity structure: Evidence from France, Germany and the UK', European Financial Management, Vol. 12(2), 2006, pp. 161-194.

Appel, I., Gormley, T. A. and Keim, D. B., 'Passive investors, not passive owners', Journal of Financial Economics, Vol. 121(1), 2016, pp. 111-141.

Bae, K., Lim, C. and Wei, J., 'Corporate governance and conditional skewness in the world's stock markets', Journal of Business, Vol. 79(6), 2006, pp. 2999-3028.

Baltagi, B. D., 'Econometric analysis of panel data', 5th Ed. Wiley, 2013.

Barclay, M. and Smith, C. W., 'The maturity structure of corporate debt', Journal of Finance, Vol. 50(2), 1995, pp. 609-631.

Barclay, M., Marx, L. and Smith, C., 'The joint determination of leverage and maturity', Journal of Corporate Finance, Vol. 9(2), 2003, pp. 149-167.

Barnea, A., Haugen, R. A. and Senbet, L. W., 'A rationale for debt maturity structure and call provisions in the agency theoretic framework', Journal of Finance, Vol. 35(5), 1980, pp. 1223-1234.

Bhojraj, S. and Sengupta, P., 'Effect of corporate governance on bond ratings and yields: The role of institutional investors and outside directors', Journal of Business, Vol. 76(3), 2003, pp. 455-475. 
Billett, M., King, T. and Mauer, D., 'Growth opportunities and the choice of leverage, debt maturity, and covenants', Journal of Finance, Vol. 62(2), 2007, pp. 697-730.

Blundell, R. and Bond, S., 'Initial conditions and moment restrictions in dynamic panel data models', Journal of Econometrics, Vol. 87(1), 1998, pp. 115-143.

Boone, A. L. and White, J. T., 'The effect of institutional ownership on firm transparency and information production', Journal of Financial Economics, Vol. 117(3), 2015, pp. 508-533.

Boot, A. W., 'Relationship banking: What do we know?' Journal of Financial Intermediation, Vol. 9(1), 2000, pp. 7-25.

Boubaker, S., Mansali, H., and Rjiba, H., 'Large controlling shareholders and stock price synchronicity', Journal of Banking \& Finance, Vol. 40, 2014, pp. 80-96.

Brockman, P., Martin, X. and Unlu, E., 'Executive compensation and the maturity structure of corporate debt', Journal of Finance, Vol. 65(3), 2010, pp. 1123-1161.

Bushee, B. J., 'Do institutional investors prefer near-term earnings over long-run value?' Contemporary Accounting Research, Vol. 18(2), 2001, pp. 207-246.

Bushee, B. J., 'The influence of institutional investors on myopic R\&D investment behavior', Accounting Review, Vol. 73(3), 1998, pp. 305-333.

Bushman, R. and Smith, A., 'Financial accounting information and corporate governance', Journal of Accounting Economics, Vol. 32(1), 2001, pp. 237-333.

Callen, J. L. and Fang, X., 'Crash risk and the auditor-client relationship', Contemporary Accounting Research, 2016, forthcoming.

Callen, J. L. and Fang, X., 'Institutional investor stability and crash risk: Monitoring versus shorttermism?' Journal of Banking \& Finance, Vol. 37(8), 2013, pp. 3047-3063.

Callen, J. L. and Fang, X., 'Religion and stock price crash risk', Journal of Financial and Quantitative Analysis, Vol. 50(1-2), 2015b, pp. 169-195.

Callen, J. L. and Fang, X., 'Short interest and stock price crash risk', Journal of Banking \& Finance, Vol. 60, 2015a, pp. 181-194. 
Chang, X., Chen, Y. and Zolotoy, L., 'Stock liquidity and stock price crash risk', Journal of Financial and Quantitative Analysis, 2016, forthcoming.

Chen, J., Hong, H. and Stein, J., 'Forecasting crashes: trading volume, past returns, and conditional skewness in stock prices', Journal of Financial Economics, Vol. 61(3), 2001, pp. 345-381.

Childs, P. D., Mauer, D. C. and Ott, S. H., 'Interactions of corporate financing and investment decisions: The effects of agency conflicts', Journal of Financial Economics, Vol. 76(3), 2005, pp. 667-690.

Custodio, C., Ferreira, M. A. and Laureano, L., ‘Why are US firms using more short-term debt?’ Journal of Financial Economics, Vol. 108(1), 2013, pp. 182-212.

Dass, N. and Massa, M., 'The impact of a strong bank-firm relationship on the borrowing firm', Review of Financial Studies, Vol. 24(4), 2011, pp. 1204-1260.

Datta, S., Iskandar-Datta, M. and Raman, K., 'Managerial stock ownership and the maturity structure of corporate debt', Journal of Finance, Vol. 60(5), 2005, pp. 2333-2350.

Dechow, P. M., Ge, W. L., Larson, C. R. and Sloan, R. G., 'Predicting material accounting misstatements', Contemporary Accounting Research, Vol. 28(1), 2011, pp. 17-82.

Dechow, P. M., Sloan, R. G. and Sweeney, A. P., 'Causes and consequences of earnings manipulation: An analysis of firms subject to enforcement actions by the SEC', Contemporary Accounting Research, Vol. 13(1), 1996, pp. 1-36.

DeFond, M. L., Hung, M., Li, S. and Li, Y., 'Does mandatory IFRS adoption affect crash risk?' Accounting Review, Vol. 90(1), 2014, pp. 265-299.

Demsetz, H. and Lehn, K., 'The structure of corporate ownership: Cause and consequences', Journal of Political Economy, Vol. 93(6), 1985, pp. 1155-1177.

Diamond, D. W., 'Debt maturity structure and liquidity risk', Quarterly Journal of Economics, Vol. 106(3), 1991a, pp. 709-737.

Diamond, D. W., 'Monitoring and reputation: The choice between bank loans and directly placed debt', Journal of Political Economy, Vol. 99(4), 1991b, pp. 689-721. 
Dimson, E., 'Risk measurement when shares are subject to infrequent trading', Journal of Financial Economics, Vol. 7(2), 1979, pp. 197-226.

Duchin, R., Ozbas, O. and Sensoy, B. A., 'Costly external finance, corporate investment, and the subprime mortgage credit crisis', Journal of Financial Economics, Vol. 97(3), 2010, pp. 418-435.

Fama, E., 'What's different about banks?' Journal of Monetary Economics, Vol. 15(1), 1985, pp. 29-39.

Faulkender, M. and Wang, R., 'Corporate financial policy and the value of cash', Journal of Finance, Vol. 61(4), 2006, pp. 1957-1990.

Fields, L. P., Gupta, M., Wilkins, M. S. and Zhang, S., 'Refinancing pressure and earnings management: Evidence from changes in short-term debt and discretionary accruals', Working paper (Texas A\&M University, 2016).

Flannery, M. J., 'Asymmetric information and risky debt maturity choice', Journal of Finance, Vol. 41(1), 1986, pp. 19-37.

Giannetti, M., 'Do better institutions mitigate agency problems? Evidence from corporate finance choices', Journal of Financial and Quantitative Analysis, Vol. 38(1), 2003, pp. 185-212.

Gompers, P., Ishii, J. and Metrick, A., 'Corporate governance and equity prices', Quarterly Journal of Economics, Vol. 118(1), 2003, pp. 107-155.

Graham, J., Leary, M. and Roberts, M. R., 'A century of capital structure: The leveraging of corporate America', Journal of Financial Economics, Vol. 118(3), 2015, pp. 658-683.

Graham, J., Li, S. and Qiu, J., 'Corporate misreporting and bank loan contracting', Journal of Financial Economics, Vol. 89(1), 2008, pp. 44-61.

Guedes, J. and Opler, T., 'The determinants of the maturity of corporate debt issues', Journal of Finance, Vol. 51(5), 1996, pp. 1809-1833.

Gul, F. A. and Goodwin, J., 'Short-term debt maturity structures, credit ratings, and the pricing of audit services', Accounting Review, Vol. 85(3), 2010, pp. 877-909.

Habib, A. and Hasan, M. M., 'Auditor-provided tax services and stock price crash risk', Accounting and Business Research, Vol. 46(1), 2015, pp. 51-82. 
Habib, A., Jiang, H. and Hasan, M. M., 'Stock price crash risk: Review of the empirical literature', Working paper (Massey University, 2016).

Hadlock, C. and Pierce, J., 'New evidence on measuring financial constraints: Moving beyond the KZ index', Review of Financial Studies, Vol. 23(5), 2010, pp. 1909-1940.

Harford, J., Klasa, S. and Maxwell, W., 'Refinancing risk and cash holdings', Journal of Finance, Vol. 69(3), 2014, pp. 975-1012.

Harvey, C. R. and Siddique, A., 'Conditional skewness in asset pricing tests', Journal of Finance, Vol. 55(3), 2000, pp. 1263-1295.

Healy, P. M. and Palepu, K. G., 'Information asymmetry, corporate disclosure, and the capital markets: A review of the empirical disclosure literature', Journal of Accounting and Economics, Vol. 31(1), 2001, pp. $405-440$.

Huang, R., Tan, K. J. K. and Faff, R. W., 'CEO overconfidence and corporate debt maturity', Journal of Corporate Finance, Vol. 36, 2016, pp. 93-110.

Hutton, A. P., Marcus, A. J. and Tehranian, H., 'Opaque financial reports, ${ }^{2}$, and crash risk', Journal of Financial Economics, Vol. 94(1), 2009, pp. 67-86.

Jin, L. and Myers, C. S., 'R ${ }^{2}$, around the world: New theory and new tests', Journal of Financial Economics, Vol. 79(2), 2006, pp. 257-292.

Johnson, S. A., 'Debt maturity and the effects of growth opportunities and liquidity risk on leverage', Review of Financial Studies, Vol. 16(2), 2003, pp. 209-236.

Kaplan, S. and Zingales, L., 'Do investment-cash flow sensitivities provide useful measures of financing constraints?' Quarterly Journal of Economics, Vol. 112(1), 1997, pp. 169-215.

Kim, J. B. and Zhang, L., 'Accounting conservatism and stock price crash risk: Firm-level evidence', Contemporary Accounting Research, Vol. 33(1), 2016, pp. 412-441.

Kim, J. B., Li, Y. and Zhang, L., 'CFO versus CEO: Equity incentives and crashes', Journal of Financial Economics, Vol. 101(3), 2011a, pp. 713-730. 
Kim, J. B., Li, Y. and Zhang, L., 'Corporate tax avoidance and stock price crash risk: Firm-level analysis', Journal of Financial Economics, Vol. 100(3), 2011b, pp. 639-662.

Kim, J. B., Wang, Z. and Zhang, L., 'CEO overconfidence and stock price crash risk', Contemporary Accounting Research, 2016, forthcoming.

Kim, Y., Li, H. and Li, S., 'Corporate social responsibility and stock price crash risk', Journal of Banking \& Finance, Vol. 43(6), 2014, pp. 1-13.

Kothari, S. P., Shu, S. and Wysocki, P. D., 'Do managers withhold bad news?' Journal of Accounting Research, Vol. 47(1), 2009, pp. 241-276.

Lee, E., Strong, N. and Zhu, Z., 'Did regulation fair disclosure, SOX, and other analyst regulations reduce security mispricing?' Journal of Accounting Research, Vol. 52(3), 2014, pp. 733-774.

Leland, H. E. and Toft, K. B., 'Optimal capital structure, endogenous bankruptcy, and the term structure of credit spreads', Journal of Finance, Vol. 51(3), 1996, pp. 987-1019.

Myers, S. C., 'Determinants of corporate borrowing', Journal of Financial Economics, Vol. 5(2), 1977, pp. 147-175.

Ozkan, A., 'An empirical analysis of corporate debt maturity structure', European Financial Management, Vol. 6(2), 2000, pp. 197-212.

Öztekin, O., 'Capital structure decisions around the world: Which factors are reliably important?' Journal of Financial and Quantitative Analysis, Vol. 50(3), 2015, pp. 301-323.

Rajan, R. and Winton, A., 'Covenants and collateral as incentives to monitor', Journal of Finance, Vol. 50(4), 1995, pp. 1113-1146.

Roberts, M. R. and Sufi, A., 'Renegotiation of financial contracts: Evidence from private credit agreements', Journal of Financial Economics, Vol. 93(2), 2009, pp. 159-184.

Roberts, M. R., 'The role of dynamic renegotiation and asymmetric information in financial contracting', Journal of Financial Economics, Vol. 116(1), 2015, pp. 61-81. 
Sheard, P., 'The main bank system and corporate monitoring and control in Japan', Journal of Economic Behavior \& Organization, Vol. 11(3), 1989, pp. 399-422.

Stohs, M. H. and Mauer, D. C., 'The determinants of corporate debt maturity structure', Journal of Business, Vol. 69(3), 1996, pp. 279-312.

Stulz, R., 'Does financial structure matter for economic growth? A corporate finance perspective', Financial structure and economic growth: A cross-country comparison of banks, markets, and development, 2001, pp. 143-188.

Vashishtha, R., 'The role of bank monitoring in borrowers' discretionary disclosure: Evidence from covenant violations', Journal of Accounting and Economics, Vol. 57(2), 2014, pp.176-195.

Whited, T. and Wu, G., 'Financial constraints risk', Review of Financial Studies, Vol. 19(2), 2006, pp. 531-559.

Williamson, O. E., 'Corporate finance and corporate governance', The Journal of Finance, Vol. 43(3), 1988, pp. 567-591.

Xu, N., Li, X., Yuan, Q., and Chan, K. C. 'Excess perks and stock price crash risk: Evidence from China', Journal of Corporate Finance, Vol. 25, 2014, 419-434.

Zhang, F., 'Information uncertainty and analyst forecast behavior', Contemporary Accounting Research, Vol. 23(2), 2006, pp. 565-590. 
Table 1

\section{Descriptive Statistics}

The table reports the descriptive statistics and correlation matrix for the variables used in our study. Variable definitions are provided in the Appendix. All variables are winsorized at the $1 \%$ and $99 \%$ levels.

\begin{tabular}{lcccccccc}
\hline Variable & $\mathrm{N}$ & Mean & Std. dev. & $5^{\text {th }}$ & $25^{\text {th }}$ & Median & $75^{\text {th }}$ & $95^{\text {th }}$ \\
\hline NCSKEW $_{\mathrm{t}}$ & 53,052 & -0.085 & 0.748 & -1.283 & -0.502 & -0.104 & 0.302 & 1.199 \\
DUVOL $_{\mathrm{t}}$ & 53,052 & -0.055 & 0.352 & -0.627 & -0.290 & -0.065 & 0.170 & 0.554 \\
CRASH $_{\mathrm{t}}$ & 53,052 & 0.182 & 0.386 & 0.000 & 0.000 & 0.000 & 0.000 & 1.000 \\
COUNT $_{\mathrm{t}}$ & 53,052 & -0.037 & 0.632 & -1.000 & 0.000 & 0.000 & 0.000 & 1.000 \\
ST3 $_{\mathrm{t}-1}$ & 53,052 & 0.541 & 0.356 & 0.008 & 0.217 & 0.515 & 0.938 & 1.000 \\
DTURN $_{\mathrm{t}-1}$ & 53,052 & 0.028 & 0.792 & -1.100 & -0.207 & 0.000 & 0.223 & 1.279 \\
SIGMA $_{\mathrm{t}-1}$ & 53,052 & 0.056 & 0.029 & 0.021 & 0.034 & 0.049 & 0.071 & 0.114 \\
RET $_{\mathrm{t}-1}$ & 53,052 & -0.198 & 0.223 & -0.647 & -0.247 & -0.120 & -0.058 & -0.022 \\
SIZE $_{\mathrm{t}-1}$ & 53,052 & 5.752 & 2.202 & 2.330 & 4.083 & 5.665 & 7.278 & 9.622 \\
MB $_{\mathrm{t}-1}$ & 53,052 & 2.675 & 2.624 & 0.592 & 1.184 & 1.892 & 3.103 & 7.499 \\
LEV $_{\mathrm{t}-1}$ & 53,052 & 0.239 & 0.171 & 0.006 & 0.098 & 0.222 & 0.351 & 0.558 \\
ROA $_{\mathrm{t}-1}$ & 53,052 & 0.014 & 0.129 & -0.225 & 0.001 & 0.039 & 0.075 & 0.143 \\
NCSKEW $_{\mathrm{t}-1}$ & 53,052 & -0.085 & 0.776 & -1.258 & -0.500 & -0.108 & 0.294 & 1.164 \\
ACCM $_{\mathrm{t}-1}$ & 53,052 & 0.069 & 0.082 & 0.004 & 0.019 & 0.042 & 0.085 & 0.230 \\
INST $_{\mathrm{t}-1}$ & 43,063 & 0.455 & 0.301 & 0.017 & 0.181 & 0.445 & 0.710 & 0.951 \\
LTINST $_{\mathrm{t}-1}$ & 43,063 & 0.339 & 0.238 & 0.010 & 0.129 & 0.319 & 0.521 & 0.748 \\
GINDEX $_{\mathrm{t}-1}$ & 12,230 & 9.456 & 2.983 & 5.000 & 7.000 & 9.000 & 12.000 & 14.000 \\
FERR $_{\mathrm{t}-1}$ & 34,298 & 0.531 & 1.551 & 0.006 & 0.038 & 0.108 & 0.318 & 2.207 \\
DISPER $_{\mathrm{t}-1}$ & 33,631 & 0.122 & 0.794 & -0.626 & 0.031 & 0.083 & 0.202 & 0.886 \\
RD $_{\mathrm{t}-1}$ & 31,513 & 0.059 & 0.086 & 0.000 & 0.004 & 0.026 & 0.077 & 0.227 \\
RATEDUM $_{\mathrm{t}-1}$ & 53,052 & 0.302 & 0.459 & 0.000 & 0.000 & 0.000 & 1.000 & 1.000 \\
\hline
\end{tabular}


Table 2

The Impact of Short-term Debt on Future Stock Price Crash Risk

This table presents the regression results for Model (4), in which we regress stock price crash risk on short-term debt and the control variables. Variable definitions are provided in the Appendix. All variables except year and industry dummies are winsorized at the $1 \%$ and $99 \%$ levels. $T$-statistics are reported in parentheses and are based on standard errors that are corrected for heteroskedasticity and clustered at the firm level. ***,**, and * indicate significance of the coefficients at the $1 \%, 5 \%$, and $10 \%$ levels, respectively (two-sided).

\begin{tabular}{|c|c|c|c|c|c|c|c|}
\hline & $\begin{array}{c}\text { Predicted } \\
\text { Sign }\end{array}$ & $\begin{array}{c}(1) \\
\text { NCSKEW }_{\mathrm{t}}\end{array}$ & $\begin{array}{c}(2) \\
\text { NCSKEW }_{\mathrm{t}}\end{array}$ & $\begin{array}{c}(3) \\
\text { NCSKEW }_{t}\end{array}$ & $\begin{array}{c}(4) \\
\text { DUVOL }_{t}\end{array}$ & $\begin{array}{c}(5) \\
\text { DUVOL }_{t}\end{array}$ & $\begin{array}{c}(6) \\
\text { DUVOL }_{t}\end{array}$ \\
\hline $\mathrm{ST}_{\mathrm{t}-1}$ & - & $\begin{array}{c}-0.039 * * * \\
(-3.53)\end{array}$ & $\begin{array}{c}-0.041 * * * \\
(-3.74)\end{array}$ & $\begin{array}{c}-0.048 * * * \\
(-4.30)\end{array}$ & $\begin{array}{c}-0.020 * * * \\
(-3.89)\end{array}$ & $\begin{array}{c}-0.021 * * * \\
(-4.17)\end{array}$ & $\begin{array}{c}-0.023 * * * \\
(-4.57)\end{array}$ \\
\hline DTURN $_{t-1}$ & + & $\begin{array}{c}0.036^{* * *} \\
(8.58)\end{array}$ & $\begin{array}{c}0.036^{* * *} \\
(8.61)\end{array}$ & $\begin{array}{c}0.037 * * * \\
(8.76)\end{array}$ & $\begin{array}{c}0.017 * * * \\
(8.94)\end{array}$ & $\begin{array}{c}0.017 * * * \\
(9.06)\end{array}$ & $\begin{array}{c}0.018^{* * *} \\
(9.12)\end{array}$ \\
\hline SIGMA $_{t-1}$ & + & $\begin{array}{c}3.428 * * * \\
(7.53)\end{array}$ & $\begin{array}{c}3.394 * * * \\
(7.13)\end{array}$ & $\begin{array}{c}3.144 * * * \\
(6.47)\end{array}$ & $\begin{array}{c}1.258 * * * \\
(5.84)\end{array}$ & $\begin{array}{c}1.192 * * * \\
(5.31)\end{array}$ & $\begin{array}{c}1.106^{* * *} \\
(4.83)\end{array}$ \\
\hline $\mathrm{RET}_{\mathrm{t}-1}$ & + & $\begin{array}{c}0.489 * * * \\
(8.67)\end{array}$ & $\begin{array}{c}0.506^{* * *} \\
(8.83)\end{array}$ & $\begin{array}{c}0.485^{* * *} \\
(8.38)\end{array}$ & $\begin{array}{c}0.193 * * * \\
(7.23)\end{array}$ & $\begin{array}{c}0.199 * * * \\
(7.37)\end{array}$ & $\begin{array}{c}0.192 * * * \\
(7.04)\end{array}$ \\
\hline $\mathrm{SIZE}_{\mathrm{t}-1}$ & + & $\begin{array}{c}0.049 * * * \\
(23.33)\end{array}$ & $\begin{array}{c}0.046^{* * *} \\
(20.12)\end{array}$ & $\begin{array}{c}0.047 * * * \\
(19.93)\end{array}$ & $\begin{array}{c}0.023 * * * \\
(23.30)\end{array}$ & $\begin{array}{c}0.021 * * * \\
(19.62)\end{array}$ & $\begin{array}{c}0.021 * * * \\
(19.14)\end{array}$ \\
\hline $\mathrm{MB}_{\mathrm{t}-1}$ & + & $\begin{array}{c}0.016^{* * *} \\
(11.38)\end{array}$ & $\begin{array}{c}0.016^{* * *} \\
(11.27)\end{array}$ & $\begin{array}{c}0.015 * * * \\
(10.93)\end{array}$ & $\begin{array}{c}0.007 * * * \\
(11.22)\end{array}$ & $\begin{array}{c}0.007 * * * \\
(11.24)\end{array}$ & $\begin{array}{c}0.008^{* * *} \\
(11.23)\end{array}$ \\
\hline $\mathrm{LEV}_{\mathrm{t}-1}$ & - & $\begin{array}{c}-0.133 * * * \\
(-6.26)\end{array}$ & $\begin{array}{c}-0.133^{* * *} \\
(-6.29)\end{array}$ & $\begin{array}{c}-0.112 * * * \\
(-5.04)\end{array}$ & $\begin{array}{c}-0.059 * * * \\
(-5.93)\end{array}$ & $\begin{array}{c}-0.060 * * * \\
(-6.06)\end{array}$ & $\begin{array}{c}-0.054 * * * \\
(-5.16)\end{array}$ \\
\hline $\mathrm{ROA}_{\mathrm{t}-1}$ & $+/-$ & $\begin{array}{c}0.388 * * * \\
(12.89)\end{array}$ & $\begin{array}{c}0.380 * * * \\
(12.60)\end{array}$ & $\begin{array}{c}0.373 * * * \\
(12.16)\end{array}$ & $\begin{array}{c}0.194 * * * \\
(14.04)\end{array}$ & $\begin{array}{c}0.189 * * * \\
(13.65)\end{array}$ & $\begin{array}{c}0.183 * * * \\
(12.96)\end{array}$ \\
\hline NCSKEW $_{\mathrm{t}-1}$ & + & $\begin{array}{c}0.021 * * * \\
(4.42)\end{array}$ & $\begin{array}{c}0.021 * * * \\
(4.41)\end{array}$ & $\begin{array}{c}0.019 * * * \\
(3.99)\end{array}$ & $\begin{array}{c}0.010 * * * \\
(4.61)\end{array}$ & $\begin{array}{c}0.010^{* * *} \\
(4.66)\end{array}$ & $\begin{array}{c}0.009 * * * \\
(4.33)\end{array}$ \\
\hline $\mathrm{ACCM}_{\mathrm{t}-1}$ & + & $\begin{array}{c}0.198 * * * \\
(4.26)\end{array}$ & $\begin{array}{c}0.196 * * * \\
(4.24)\end{array}$ & $\begin{array}{c}0.179 * * * \\
(3.85)\end{array}$ & $\begin{array}{c}0.090 * * * \\
(4.23)\end{array}$ & $\begin{array}{c}0.088 * * * \\
(4.15)\end{array}$ & $\begin{array}{c}0.081 * * * \\
(3.79)\end{array}$ \\
\hline Intercept & & $\begin{array}{c}-0.468 * * * \\
(-18.19)\end{array}$ & $\begin{array}{c}-0.539 * * * \\
(-17.39)\end{array}$ & $\begin{array}{c}-0.598 * * * \\
(-7.88)\end{array}$ & $\begin{array}{c}-0.220 * * * \\
(-18.28)\end{array}$ & $\begin{array}{c}-0.256 * * * \\
(-17.83)\end{array}$ & $\begin{array}{c}-0.283 * * * \\
(-7.83)\end{array}$ \\
\hline Year FE & & No & Yes & Yes & No & Yes & Yes \\
\hline Industry FE & & No & No & Yes & No & No & Yes \\
\hline $\mathrm{N}$ & & 53,052 & 53,052 & 53,052 & 53,052 & 53,052 & 53,052 \\
\hline Adjusted $\mathrm{R}^{2}$ & & 0.039 & 0.045 & 0.047 & 0.041 & 0.049 & 0.050 \\
\hline
\end{tabular}


Table 3

\section{Dealing with Endogeneity}

This table presents two tests to address endogeneity concerns in the baseline regression of future stock price crash risk on short-term debt maturity. Panel A presents the results from the firm fixed-effects (FE) regressions (Columns (1) and (2)) and the first-differences (FD) regressions (Columns (3) and (4)). In the FE regressions, we report the within $R$-squared. Panel B reports the system generalized method of moments (SYSGMM) regression results. In the levels equations, our instruments for $N C S K E W_{t-1}$ and $S T 3_{t-1}$ include their lagged values in first differences. In the first-differenced equations, our instruments for $\triangle N C S K E W_{t-1}$ and $\triangle S T 3_{t-1}$ are the lagged values of $N C S K E W_{t-1}$ and $S T 3_{t-1}$, both in levels. $A R 1$ and $A R 2 p$-values are the $p$-values of the tests for first- and second-order autocorrelation in the residuals, under the null of no autocorrelation, respectively. $J$-test is the Sargan/Hansen test for overidentification of the instruments, under the null of non-overidentification; the number of overidentified instruments is provided in brackets. $V I Y$ refers to a set of controls including all explanatory variables, industry effects, and year effects. Variable definitions are provided in the Appendix. All variables except year and industry dummies are winsorized at the $1 \%$ and $99 \%$ levels. $T$-statistics are reported in parentheses and are based on standard errors that are corrected for heteroskedasticity and clustered at the firm level. ***,**, and * indicate significance of the coefficients at the $1 \%, 5 \%$, and $10 \%$ levels, respectively (two-sided).

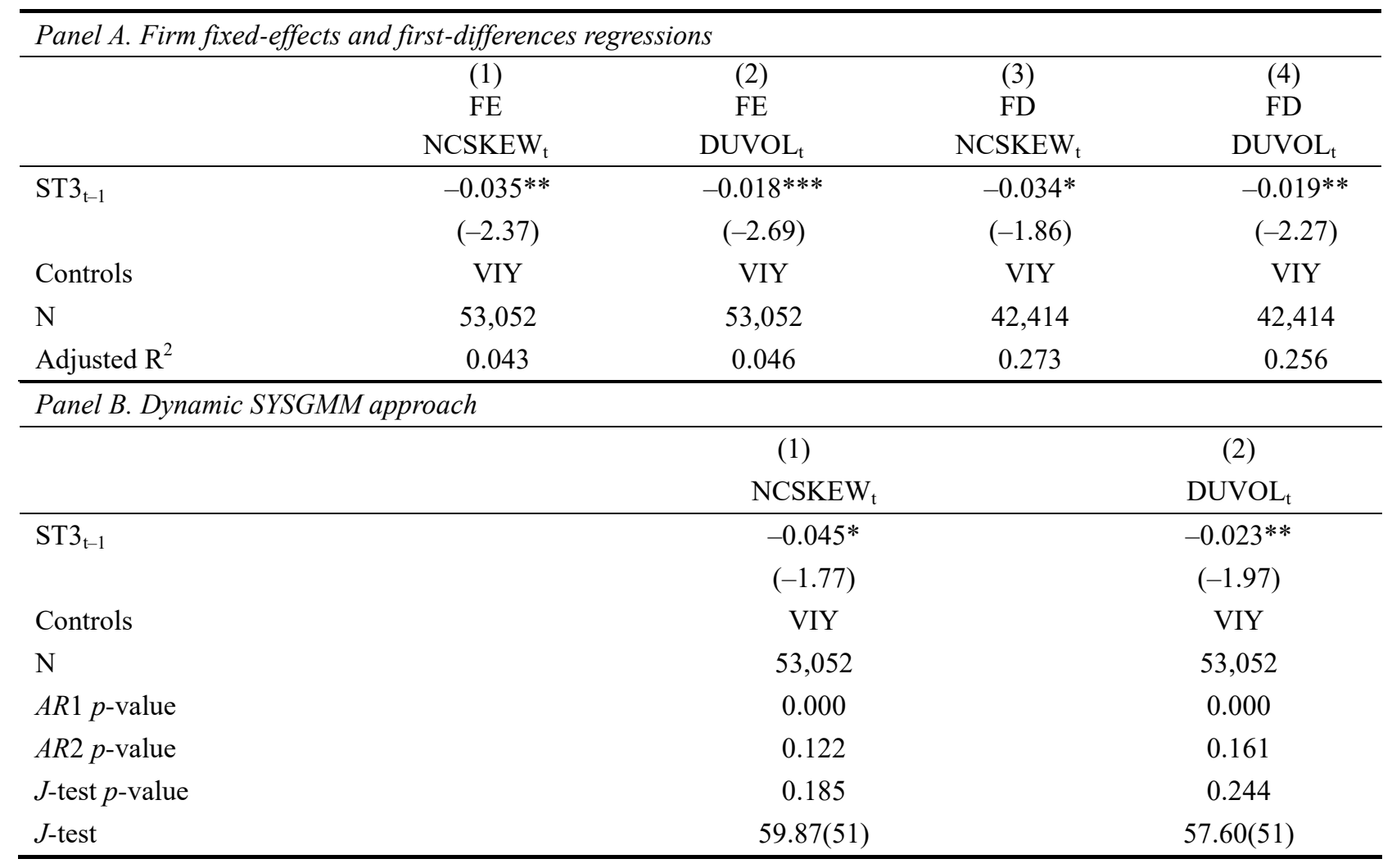


Table 4

\section{Other Robustness Checks}

This table presents the results of other robustness checks. In Panel A, we use alternative measures of short-term debt, including the ratio of debt in current liabilities to total debt $(S T 1)$, the ratio of debt in current liabilities plus debt maturing in two years to total debt (ST2), the ratio of debt in current liabilities plus debt maturing in five years to total debt (ST5), the ratio of debt in current liabilities plus debt maturing in three years to total assets (ST3_TA), and the ratio of debt in current liabilities minus long-term debt due in one year to total debt (STNP1). In Panel B, crash risk is proxied by CRASH and COUNT. CRASH is an indicator variable that takes one if a firm experiences more than one price crash week in a fiscal year. COUNT is the number of crash weeks minus the number of jump weeks over the fiscal year. In the logistic regressions of $C R A S H$, we present the marginal effects in square brackets; we also report the pseudo $R$-squared for those regressions. In Panel C, we use an alternative measure of leverage, i.e., long-term debt divided by total assets. In Panel D, we further control for variables that capture fundamental risk, including earnings volatility, cash flow volatility, sales volatility, and beta risk. VIY refers to a set of controls including all explanatory variables, industry effects, and year effects. Variable definitions are provided in the Appendix. All variables except year and industry dummies are winsorized at the $1 \%$ and $99 \%$ levels. $T$-statistics (Z-statistics) are reported in parentheses and are based on standard errors that are corrected for heteroskedasticity and clustered at the firm level. ***, **, and * indicate significance of the coefficients at the $1 \%, 5 \%$, and $10 \%$ levels, respectively (two-sided).

\begin{tabular}{|c|c|c|c|c|c|c|c|c|c|c|}
\hline \multicolumn{11}{|c|}{ Panel A. Alternative measures of short-term debt } \\
\hline & (1) & (2) & (3) & (4) & (5) & (6) & (7) & (8) & (9) & (10) \\
\hline & NCSKEW $_{t}$ & DUVOL $_{t}$ & NCSKEW $_{t}$ & DUVOL $_{t}$ & $\mathrm{NCSKEW}_{\mathrm{t}}$ & DUVOL $_{t}$ & $\mathrm{NCSKEW}_{\mathrm{t}}$ & DUVOL $_{t}$ & $\mathrm{NCSKEW}_{\mathrm{t}}$ & DUVOL $_{t}$ \\
\hline \multirow[t]{2}{*}{$\mathrm{ST} 1_{\mathrm{t}-1}$} & $-0.037 * * *$ & $-0.015 * * *$ & & & & & & & & \\
\hline & $(-3.06)$ & $(-2.67)$ & & & & & & & & \\
\hline \multirow[t]{2}{*}{$\mathrm{ST} 2_{\mathrm{t}-1}$} & & & $-0.053^{* * *}$ & $-0.023 * * *$ & & & & & & \\
\hline & & & $(-4.64)$ & $(-4.49)$ & & & & & & \\
\hline \multirow[t]{2}{*}{$\mathrm{ST}_{\mathrm{t}-1}$} & & & & & $-0.023^{*}$ & $-0.011^{*}$ & & & & \\
\hline & & & & & $(-1.81)$ & $(-1.86)$ & & & & \\
\hline \multirow[t]{2}{*}{ ST3_TA ${ }_{t-1}$} & & & & & & & $-0.224 * * *$ & $-0.103 * * *$ & & \\
\hline & & & & & & & $(-5.98)$ & $(-5.97)$ & & \\
\hline \multirow[t]{2}{*}{$\mathrm{STNP} 1_{\mathrm{t}-1}$} & & & & & & & & & $-0.045 * * *$ & $-0.019 * * *$ \\
\hline & & & & & & & & & $(-3.49)$ & $(-3.23)$ \\
\hline Controls & VIY & VIY & VIY & VIY & VIY & VIY & VIY & VIY & VIY & VIY \\
\hline $\mathrm{N}$ & 53,052 & 53,052 & 53,052 & 53,052 & 51,646 & 51,646 & 53,052 & 53,052 & 52,505 & 52,505 \\
\hline Adjusted $\mathrm{R}^{2}$ & 0.046 & 0.050 & 0.047 & 0.050 & 0.046 & 0.050 & 0.047 & 0.050 & 0.047 & 0.050 \\
\hline
\end{tabular}




\begin{tabular}{|c|c|c|c|c|c|c|c|c|c|c|c|c|}
\hline \multicolumn{13}{|c|}{ Panel B. Alternative measures of crash risk } \\
\hline & (1) & (2) & (3) & (4) & (5) & (6) & (7) & (8) & (9) & (10) & (11) & (12) \\
\hline & $\mathrm{CRASH}_{\mathrm{t}}$ & $\mathrm{COUNT}_{\mathrm{t}}$ & $\mathrm{CRASH}_{\mathrm{t}}$ & $\mathrm{COUNT}_{\mathrm{t}}$ & $\mathrm{CRASH}_{\mathrm{t}}$ & $\mathrm{COUNT}_{\mathrm{t}}$ & $\mathrm{CRASH}_{\mathrm{t}}$ & COUNT $_{t}$ & $\mathrm{CRASH}_{\mathrm{t}}$ & COUNT $_{t}$ & $\mathrm{CRASH}_{\mathrm{t}}$ & COUNT $_{\mathrm{t}}$ \\
\hline \multirow[t]{3}{*}{$\mathrm{ST}_{\mathrm{t}-1}$} & -0.033 & $-0.025 * *$ & & & & & & & & & & \\
\hline & {$[-0.005]$} & & & & & & & & & & & \\
\hline & $(-0.79)$ & $(-2.46)$ & & & & & & & & & & \\
\hline \multirow[t]{3}{*}{$\mathrm{ST} 2_{\mathrm{t}-1}$} & & & $-0.074 *$ & $-0.038^{* * *}$ & & & & & & & & \\
\hline & & & {$[-0.011]$} & & & & & & & & & \\
\hline & & & $(-1.84)$ & $(-4.00)$ & & & & & & & & \\
\hline \multirow[t]{3}{*}{$\mathrm{ST}_{\mathrm{t}-1}$} & & & & & $-0.071^{*}$ & $-0.033 * * *$ & & & & & & \\
\hline & & & & & {$[-0.010]$} & & & & & & & \\
\hline & & & & & $(-1.79)$ & $(-3.56)$ & & & & & & \\
\hline \multirow[t]{3}{*}{$\mathrm{ST}_{\mathrm{t}-1}$} & & & & & & & -0.008 & -0.016 & & & & \\
\hline & & & & & & & {$[-0.001]$} & & & & & \\
\hline & & & & & & & $(-0.17)$ & $(-1.50)$ & & & & \\
\hline \multirow[t]{3}{*}{ ST3_TA $\mathrm{t}_{\mathrm{t}-1}$} & & & & & & & & & $-0.315^{* *}$ & $-0.172 * * *$ & & \\
\hline & & & & & & & & & {$[-0.046]$} & & & \\
\hline & & & & & & & & & $(-2.23)$ & $(-5.41)$ & & \\
\hline \multirow[t]{3}{*}{$\operatorname{STNP} 1_{t-1}$} & & & & & & & & & & & $-0.086^{*}$ & $-0.025^{* *}$ \\
\hline & & & & & & & & & & & {$[-0.125]$} & \\
\hline & & & & & & & & & & & $(-1.87)$ & $(-2.37)$ \\
\hline Controls & VIY & VIY & VIY & VIY & VIY & VIY & VIY & VIY & VIY & VIY & VIY & VIY \\
\hline $\mathrm{N}$ & 53,052 & 53,052 & 53,052 & 53,052 & 53,052 & 53,052 & 51,646 & 51,646 & 53,052 & 53,052 & 52,505 & 52,505 \\
\hline Adj./Pseudo R $^{2}$ & 0.020 & 0.027 & 0.020 & 0.028 & 0.020 & 0.028 & 0.021 & 0.027 & 0.020 & 0.028 & 0.020 & 0.028 \\
\hline
\end{tabular}




\begin{tabular}{|c|c|c|c|c|}
\hline \multicolumn{5}{|c|}{ Panel C. Alternative measure of leverage } \\
\hline & (1) & (2) & (3) & (4) \\
\hline & NCSKEW $_{\mathrm{t}}$ & DUVOL $_{t}$ & $\mathrm{CRASH}_{\mathrm{t}}$ & $\mathrm{COUNT}_{\mathrm{t}}$ \\
\hline \multirow[t]{2}{*}{$\mathrm{ST}_{\mathrm{t}-1}$} & $-0.047 * * *$ & $-0.024 * * *$ & -0.066 & $-0.032 * * *$ \\
\hline & $(-3.93)$ & $(-4.37)$ & $(-1.54)$ & $(-3.08)$ \\
\hline \multirow[t]{2}{*}{ DTURN $_{t-1}$} & $0.037^{* * *}$ & $0.018^{* * *}$ & $0.093 * * *$ & $0.024 * * *$ \\
\hline & $(8.78)$ & $(9.15)$ & $(6.23)$ & $(6.57)$ \\
\hline \multirow[t]{2}{*}{ SIGMA $_{t-1}$} & $3.134 * * *$ & $1.106^{* * *}$ & 2.546 & $2.149 * * *$ \\
\hline & $(6.44)$ & $(4.83)$ & $(1.44)$ & $(5.31)$ \\
\hline \multirow[t]{2}{*}{$\mathrm{RET}_{\mathrm{t}-1}$} & $0.485 * * *$ & $0.193 * * *$ & $0.625 * * *$ & $0.322 * * *$ \\
\hline & $(8.37)$ & $(7.05)$ & $(2.87)$ & $(6.56)$ \\
\hline \multirow[t]{2}{*}{ SIZE $_{t-1}$} & $0.047^{* * *}$ & $0.021 * * *$ & $0.031 * * *$ & $0.033 * * *$ \\
\hline & $(19.96)$ & $(19.17)$ & $(3.66)$ & $(17.11)$ \\
\hline \multirow[t]{2}{*}{$\mathrm{MB}_{\mathrm{t}-1}$} & $0.015^{* * *}$ & $0.007 * * *$ & $0.021 * * *$ & $0.010 * * *$ \\
\hline & (10.79) & (11.12) & (4.59) & $(8.33)$ \\
\hline \multirow[t]{2}{*}{$\mathrm{LT}_{-} \mathrm{LEV}_{\mathrm{t}-1}$} & $-0.078 * * *$ & $-0.042 * * *$ & -0.053 & $-0.045^{* *}$ \\
\hline & $(-2.97)$ & $(-3.43)$ & $(-0.56)$ & $(-2.01)$ \\
\hline \multirow[t]{2}{*}{$\mathrm{ROA}_{\mathrm{t}-1}$} & $0.381 * * *$ & $0.186^{* * *}$ & $0.718 * * *$ & $0.253 * * *$ \\
\hline & $(12.41)$ & (13.19) & $(6.58)$ & $(10.01)$ \\
\hline \multirow[t]{2}{*}{ NCSKEW $_{\mathrm{t}-1}$} & $0.019 * * *$ & $0.009 * * *$ & $0.062 * * *$ & $0.010^{* *}$ \\
\hline & $(4.00)$ & $(4.34)$ & (3.94) & $(2.46)$ \\
\hline \multirow[t]{2}{*}{$\mathrm{ACCM}_{\mathrm{t}-1}$} & $0.180 * * *$ & $0.080 * * *$ & $0.820 * * *$ & $0.137 * * *$ \\
\hline & $(3.85)$ & $(3.78)$ & $(5.45)$ & $(3.51)$ \\
\hline \multirow[t]{2}{*}{ Intercept } & $-0.615^{* * *}$ & $-0.290 * * *$ & $-2.011 * * *$ & $-0.378 * * *$ \\
\hline & $(-8.13)$ & $(-8.03)$ & $(-8.33)$ & $(-6.42)$ \\
\hline Year FE & Yes & Yes & Yes & Yes \\
\hline Industry FE & Yes & Yes & Yes & Yes \\
\hline $\mathrm{N}$ & 53,052 & 53,052 & 53,052 & 53,052 \\
\hline Adjusted $\mathrm{R}^{2}$ & 0.046 & 0.050 & 0.020 & 0.027 \\
\hline
\end{tabular}




\begin{tabular}{|c|c|c|c|c|c|c|c|c|c|c|}
\hline \multicolumn{11}{|c|}{ Panel D. Additional controls for fundamental risk } \\
\hline & $(1)$ & (2) & (3) & (4) & $(5)$ & $(6)$ & (7) & $(8)$ & (9) & $(10)$ \\
\hline & NCSKEW $_{\mathrm{t}}$ & DUVOL $_{t}$ & NCSKEW $_{\mathrm{t}}$ & DUVOL $_{t}$ & NCSKEW $_{\mathrm{t}}$ & DUVOL $_{t}$ & NCSKEW $_{\mathrm{t}}$ & DUVOL $_{t}$ & NCSKEW $_{\mathrm{t}}$ & DUVOL $_{t}$ \\
\hline \multirow{2}{*}{$\mathrm{ST}_{\mathrm{t}-1}$} & $-0.049 * * *$ & $-0.024 * * *$ & $-0.050 * * *$ & $-0.024 * * *$ & $-0.048 * * *$ & $-0.023 * * *$ & $-0.043^{* * *}$ & $-0.021 * * *$ & $-0.045^{* * *}$ & $-0.022 * * *$ \\
\hline & $(-4.35)$ & $(-4.62)$ & $(-4.45)$ & $(-4.68)$ & $(-4.29)$ & $(-4.56)$ & $(-3.85)$ & $(-4.17)$ & $(-4.01)$ & $(-4.30)$ \\
\hline \multirow[t]{2}{*}{ EARNVOL $_{\mathrm{t}-1}$} & $-0.034 * * *$ & $-0.018 * * *$ & & & & & & & $-0.040 * * *$ & $-0.020 * * *$ \\
\hline & $(-2.98)$ & $(-3.45)$ & & & & & & & $(-3.24)$ & $(-3.45)$ \\
\hline \multirow[t]{2}{*}{ CFVOL $_{t-1}$} & & & $-0.127 *$ & $-0.077 * *$ & & & & & -0.110 & $-0.064 *$ \\
\hline & & & $(-1.71)$ & $(-2.22)$ & & & & & $(-1.39)$ & $(-1.71)$ \\
\hline \multirow[t]{2}{*}{ SALEVOL $_{\mathrm{t}-1}$} & & & & & $0.041^{*}$ & 0.015 & & & $0.058 * *$ & $0.023^{* *}$ \\
\hline & & & & & (1.74) & $(1.37)$ & & & $(2.34)$ & $(2.00)$ \\
\hline \multirow[t]{2}{*}{ BETA $_{t-1}$} & & & & & & & $0.049 * * *$ & $0.019 * * *$ & $0.050 * * *$ & $0.020 * * *$ \\
\hline & & & & & & & $(7.92)$ & $(6.81)$ & $(7.88)$ & $(6.76)$ \\
\hline Controls & VIY & VIY & VIY & VIY & VIY & VIY & VIY & VIY & VIY & VIY \\
\hline $\mathrm{N}$ & 53,052 & 53,052 & 53,052 & 53,052 & 51,646 & 51,646 & 53,052 & 53,052 & 52,505 & 52,505 \\
\hline Adjusted $\mathrm{R}^{2}$ & 0.046 & 0.050 & 0.047 & 0.050 & 0.046 & 0.050 & 0.047 & 0.050 & 0.047 & 0.050 \\
\hline
\end{tabular}


Table 5

Evidence from New Debt Issues

This table presents results regarding the effect of debt maturity on stock price crash risk using data on new debt issues. Panel A reports regression results of new debt (loan or bond) issues based on an unconsolidated sample at the transaction level. DEBT_MAT is the natural logarithm of the maturity of a new loan or bond issue. DEBT_SIZE is the natural logarithm of the amount of a new loan or bond issue. Panel B reports regression results of new loan issues based on an unconsolidated (transaction-level) sample. $L O A N \_M A T$ is the natural logarithm of the maturity of a new loan issue. LOAN_SIZE is the natural logarithm of the amount of a new loan issue. Panel C reports regression results of new loan issues based on a consolidated sample. WAVG_MAT is the natural logarithm of the issue-sizeweighted debt maturity. SUM_SIZE is the natural logarithm of the total amount of new loans or bond issues. VIY refers to a set of controls including all explanatory variables, industry effects, and year effects. Variable definitions are provided in the Appendix. All variables except year and industry dummies are winsorized at the 1\% and $99 \%$ levels. $T$-statistics are reported in parentheses and are based on standard errors that are corrected for heteroskedasticity and clustered at the firm level. ***,**, and * indicate significance of the coefficients at the $1 \%$, $5 \%$, and $10 \%$ levels, respectively (two-sided).

\begin{tabular}{|c|c|c|c|c|}
\hline \multicolumn{5}{|c|}{ Panel A. Regressions based on unconsolidated sample of new debt issues } \\
\hline & (1) & (2) & (3) & (4) \\
\hline & NCSKEW $_{\mathrm{t}}$ & DUVOL $_{t}$ & NCSKEW $_{\mathrm{t}}$ & DUVOL $_{t}$ \\
\hline \multirow[t]{2}{*}{ DEBT_MAT ${ }_{\mathrm{t}-1}$} & $0.016^{* *}$ & $0.007 * *$ & $0.019 * * *$ & $0.008 * *$ \\
\hline & $(2.48)$ & $(2.39)$ & $(2.88)$ & $(2.51)$ \\
\hline \multirow[t]{2}{*}{ DEBT_SIZE $E_{t-1}$} & & & 0.002 & 0.000 \\
\hline & & & $(0.70)$ & $(0.31)$ \\
\hline Controls & VIY & VIY & VIY & VIY \\
\hline $\mathrm{N}$ & 32,785 & 32,785 & 32,785 & 32,785 \\
\hline Adjusted $\mathrm{R}^{2}$ & 0.033 & 0.038 & 0.033 & 0.038 \\
\hline \multicolumn{5}{|c|}{ Panel B. Regressions based on unconsolidated sample of new loan issues } \\
\hline & (1) & (2) & (3) & (4) \\
\hline & NCSKEW $_{\mathrm{t}}$ & DUVOL $_{t}$ & NCSKEW $_{\mathrm{t}}$ & DUVOL $_{t}$ \\
\hline \multirow[t]{2}{*}{ LOAN_MAT $_{\mathrm{t}-1}$} & $0.023 * * *$ & $0.009 * *$ & $0.022 * * *$ & $0.009 * *$ \\
\hline & $(2.92)$ & $(2.42)$ & $(2.72)$ & $(2.24)$ \\
\hline \multirow[t]{2}{*}{ LOAN_SIZE } & & & $0.011^{*}$ & $0.005^{*}$ \\
\hline & & & $(1.92)$ & $(1.72)$ \\
\hline Controls & VIY & VIY & VIY & VIY \\
\hline $\mathrm{N}$ & 24,845 & 24,845 & 24,845 & 24,845 \\
\hline Adjusted $\mathrm{R}^{2}$ & 0.034 & 0.038 & 0.034 & 0.038 \\
\hline \multicolumn{5}{|c|}{ Panel C. Consolidated sample: Issue-size-weighted maturity of new debt issues } \\
\hline & $(1)$ & (2) & (3) & (4) \\
\hline & NCSKEW $_{\mathrm{t}}$ & DUVOL $_{t}$ & NCSKEW $_{\mathrm{t}}$ & DUVOL $_{t}$ \\
\hline \multirow[t]{2}{*}{ WAVG_MAT $_{\mathrm{t}-1}$} & $0.017 * *$ & $0.008 * *$ & $0.021^{* *}$ & $0.009 * *$ \\
\hline & $(2.09)$ & $(2.08)$ & $(2.45)$ & $(2.23)$ \\
\hline \multirow[t]{2}{*}{ SUM_SIZE $_{t-1}$} & & & 0.003 & 0.001 \\
\hline & & & (1.36) & $(0.78)$ \\
\hline Controls & VIY & VIY & VIY & VIY \\
\hline $\mathrm{N}$ & 16,685 & 16,685 & 16,685 & 16,685 \\
\hline Adjusted $\mathrm{R}^{2}$ & 0.030 & 0.034 & 0.030 & 0.034 \\
\hline
\end{tabular}


Table 6

The Impact of Short-term Debt on Future Stock Price Crash Risk:

Governance Monitoring Mechanisms

This table presents the results regarding the impact of short-term debt on future stock price crash risk conditional on the effectiveness of corporate governance mechanisms. In Panel A, we partition the sample based on the (annual) median value of the fraction of institutional ownership (INST). In Panel B, we split the sample using the (annual) median value of the fraction of long-term institutional ownership (LTINST). In Panel C, we split our sample using the (annual) median value of the lagged shareholder rights index (GINDEX). VIY refers to a set of controls including all explanatory variables, industry effects, and year effects. Variable definitions are provided in the Appendix. All variables except year and industry dummies are winsorized at the 1\% and $99 \%$ levels. $T$-statistics are reported in parentheses and are based on standard errors that are corrected for heteroskedasticity and clustered at the firm level. $* * *, * *$, and $*$ indicate significance of the coefficients at the $1 \%, 5 \%$, and $10 \%$ levels, respectively (two-sided).

\begin{tabular}{|c|c|c|c|c|}
\hline \multicolumn{5}{|c|}{ Panel A. Institutional ownership } \\
\hline \multirow{3}{*}{$\begin{array}{l}\text { Dependent variable } \\
\text { Partition }\end{array}$} & (1) & (2) & (3) & (4) \\
\hline & $\mathrm{NCSKEW}_{\mathrm{t}}$ & $\mathrm{NCSKEW}_{\mathrm{t}}$ & DUVOL $_{t}$ & DUVOL $_{t}$ \\
\hline & $\begin{array}{c}\text { Weak governance } \\
\text { (INST } \leq \text { median) }\end{array}$ & $\begin{array}{c}\text { Strong governance } \\
(\text { INST > median) }\end{array}$ & $\begin{array}{l}\text { Weak governance } \\
\text { (INST } \leq \text { median) }\end{array}$ & $\begin{array}{c}\text { Strong governance } \\
\text { (INST > median) }\end{array}$ \\
\hline \multirow[t]{2}{*}{$\mathrm{ST}_{\mathrm{t}-1}$} & $-0.033 *$ & -0.024 & $-0.019 * *$ & -0.012 \\
\hline & $(-1.91)$ & $(-1.42)$ & $(-2.42)$ & $(-1.56)$ \\
\hline Controls & VIY & VIY & VIY & VIY \\
\hline $\mathrm{N}$ & 21,538 & 21,525 & 21,538 & 21,525 \\
\hline Adjusted $\mathrm{R}^{2}$ & 0.044 & 0.024 & 0.048 & 0.026 \\
\hline \multicolumn{5}{|c|}{ Panel B. Long-term (non-transient) institutional ownership } \\
\hline \multirow{4}{*}{$\begin{array}{l}\text { Dependent variable } \\
\text { Partition }\end{array}$} & (1) & (2) & (3) & (4) \\
\hline & NCSKEW $_{\mathrm{t}}$ & NCSKEW $_{\mathrm{t}}$ & DUVOL $_{t}$ & DUVOL $_{t}$ \\
\hline & Weak governance & Strong governance & Weak governance & Strong governance \\
\hline & (LTINST $\leq$ median) & (LTINST > median) & (LTINST $\leq$ median) & $($ LTINST $>$ median) \\
\hline \multirow[t]{2}{*}{$\mathrm{ST}_{\mathrm{t}-1}$} & $-0.041 * *$ & -0.027 & $-0.022 * * *$ & $-0.014 *$ \\
\hline & $(-2.33)$ & $(-1.59)$ & $(-2.76)$ & $(-1.75)$ \\
\hline Controls & VIY & VIY & VIY & VIY \\
\hline $\mathrm{N}$ & 21,538 & 21,525 & 21,538 & 21,525 \\
\hline Adjusted $\mathrm{R}^{2}$ & 0.044 & 0.025 & 0.049 & 0.028 \\
\hline \multicolumn{5}{|c|}{ Panel C. Shareholder rights } \\
\hline \multirow{4}{*}{$\begin{array}{l}\text { Dependent variable } \\
\text { Partition }\end{array}$} & (1) & (2) & (3) & (4) \\
\hline & NCSKEW $_{\mathrm{t}}$ & NCSKEW $_{\mathrm{t}}$ & DUVOL $_{t}$ & DUVOL $_{t}$ \\
\hline & Weak governance & Strong governance & Weak governance & Strong governance \\
\hline & (GINDEX $\geq$ median $)$ & $($ GINDEX < median $)$ & (GINDEX $\geq$ median) & $($ GINDEX $<$ median $)$ \\
\hline \multirow[t]{2}{*}{$\mathrm{ST} 3_{\mathrm{t}-1}$} & $-0.085 * * *$ & -0.041 & $-0.047 * * *$ & -0.024 \\
\hline & $(-2.63)$ & $(-1.30)$ & $(-3.20)$ & $(-1.63)$ \\
\hline Controls & VIY & VIY & VIY & VIY \\
\hline $\mathrm{N}$ & 7,045 & 5,185 & 7,045 & 5,185 \\
\hline Adjusted $\mathrm{R}^{2}$ & 0.019 & 0.029 & 0.022 & 0.030 \\
\hline
\end{tabular}


Table 7

The Impact of Short-term Debt on Future Stock Price Crash Risk:

The Role of Information Asymmetry

This table presents the results regarding the impact of short-term debt on future stock price crash risk conditional on the degrees of information asymmetry $(I A)$. In Panel A, we partition our sample based on the (annual) median value of analyst forecast error (FERR). In Panel B, we split our sample based on the (annual) median value of the dispersion of analysts' forecasts (DISPER). In Panel C, we partition our sample based on the (annual) median value of the R\&D ratio. VIY refers to a set of controls including all explanatory variables, industry effects, and year effects. Variable definitions are provided in the Appendix. All variables except year and industry dummies are winsorized at the $1 \%$ and $99 \%$ levels. $T$-statistics are reported in parentheses and are based on standard errors that are corrected for heteroskedasticity and clustered at the firm level. ***,**, and * indicate significance of the coefficients at the $1 \%, 5 \%$, and $10 \%$ levels, respectively (two-sided).

\begin{tabular}{|c|c|c|c|c|}
\hline \multicolumn{5}{|c|}{ Panel A. Analyst forecast error } \\
\hline \multirow{4}{*}{$\begin{array}{l}\text { Dependent variable } \\
\text { Partition }\end{array}$} & $(1)$ & $(2)$ & (3) & (4) \\
\hline & NCSKEW $_{\mathrm{t}}$ & NCSKEW $_{\mathrm{t}}$ & DUVOL $_{t}$ & DUVOL $_{t}$ \\
\hline & High IA & Low IA & High IA & Low IA \\
\hline & (FERR $\geq$ median) & $($ FERR $<$ median $)$ & (FERR $\geq$ median) & $($ FERR $<$ median $)$ \\
\hline \multirow[t]{2}{*}{$\mathrm{ST}_{\mathrm{t}-1}$} & $-0.077 * * *$ & -0.021 & $-0.037 * * *$ & $-0.016^{*}$ \\
\hline & $(-4.26)$ & $(-1.11)$ & $(-4.30)$ & $(-1.77)$ \\
\hline Controls & VIY & VIY & VIY & VIY \\
\hline $\mathrm{N}$ & 17,154 & 17,144 & 17,154 & 17,144 \\
\hline Adjusted $\mathrm{R}^{2}$ & 0.037 & 0.023 & 0.042 & 0.024 \\
\hline \multicolumn{5}{|c|}{ Panel B. Dispersion of analyst forecasts } \\
\hline \multirow{4}{*}{$\begin{array}{l}\text { Dependent variable } \\
\text { Partition }\end{array}$} & $(1)$ & (2) & (3) & (4) \\
\hline & NCSKEW $_{t}$ & NCSKEW $_{\mathrm{t}}$ & DUVOL $_{t}$ & DUVOL $_{t}$ \\
\hline & High IA & Low IA & High IA & Low IA \\
\hline & (DISPER $\geq$ median) & (DISPER < median) & (DISPER $\geq$ median) & (DISPER $<$ median) \\
\hline \multirow[t]{2}{*}{$\mathrm{ST}_{\mathrm{t}-1}$} & $-0.084 * * *$ & -0.023 & $-0.040 * * *$ & $-0.015^{*}$ \\
\hline & $(-4.60)$ & $(-1.19)$ & $(-4.71)$ & $(-1.72)$ \\
\hline Controls & VIY & VIY & VIY & VIY \\
\hline $\mathrm{N}$ & 16,822 & 16,809 & 16,822 & 16,809 \\
\hline Adjusted $\mathrm{R}^{2}$ & 0.030 & 0.031 & 0.035 & 0.034 \\
\hline \multicolumn{5}{|c|}{ Panel C. $R \& D$ intensity } \\
\hline \multirow{4}{*}{$\begin{array}{l}\text { Dependent variable } \\
\text { Partition }\end{array}$} & (1) & (2) & (3) & (4) \\
\hline & NCSKEW $_{t}$ & NCSKEW $_{\mathrm{t}}$ & DUVOL $_{t}$ & DUVOL $_{t}$ \\
\hline & High IA & Low IA & High IA & Low IA \\
\hline & $(\mathrm{RD} \geq$ median $)$ & $(\mathrm{RD}<$ median $)$ & $(\mathrm{RD} \geq$ median $)$ & $(\mathrm{RD}<$ median $)$ \\
\hline \multirow[t]{2}{*}{$\mathrm{ST}_{\mathrm{t}-1}$} & $-0.048 * *$ & -0.033 & $-0.025 * * *$ & -0.012 \\
\hline & $(-2.34)$ & $(-1.61)$ & $(-2.67)$ & $(-1.33)$ \\
\hline Controls & VIY & VIY & VIY & VIY \\
\hline $\mathrm{N}$ & 15,763 & 15,750 & 15,763 & 15,750 \\
\hline Adjusted $\mathrm{R}^{2}$ & 0.056 & 0.044 & 0.061 & 0.046 \\
\hline
\end{tabular}


Table 8

The Impact of Short-term Debt on Future Stock Price Crash Risk: Firm Risk Mechanism

This table presents the results regarding the impact of short-term debt on future stock price crash risk conditional on the degree of firm risk. In Panel A, we partition our sample based on the (annual) median value of leverage ( $L E V)$. In Panel B, we analyze unrated and rated firms separately. VIY refers to a set of controls including all explanatory variables, industry effects, and year effects. Variable definitions are provided in the Appendix. All variables except year and industry dummies are winsorized at the $1 \%$ and $99 \%$ levels. $T$-statistics are reported in parentheses and are based on standard errors that are corrected for heteroskedasticity and clustered at the firm level. ***, **, and * indicate significance of the coefficients at the $1 \%, 5 \%$, and $10 \%$ levels, respectively (two-sided).

\begin{tabular}{|c|c|c|c|c|}
\hline \multicolumn{5}{|l|}{ Panel A. Leverage } \\
\hline \multirow{4}{*}{$\begin{array}{l}\text { Dependent variable } \\
\text { Partition }\end{array}$} & (1) & (2) & (3) & (4) \\
\hline & NCSKEW $_{\mathrm{t}}$ & NCSKEW $_{\mathrm{t}}$ & DUVOL $_{t}$ & DUVOL $_{t}$ \\
\hline & High risk & Low risk & High risk & Low risk \\
\hline & (LEV $\geq$ median) & $(\mathrm{LEV}<$ median $)$ & (LEV $\geq$ median) & $(\mathrm{LEV}<$ median $)$ \\
\hline \multirow[t]{2}{*}{$\mathrm{ST} 3_{\mathrm{t}-1}$} & $-0.093 * * *$ & -0.010 & $-0.040 * * *$ & -0.011 \\
\hline & $(-5.76)$ & $(-0.65)$ & $(-5.33)$ & $(-1.50)$ \\
\hline Controls & VIY & VIY & VIY & VIY \\
\hline $\mathrm{N}$ & 26,534 & 26,518 & 26,534 & 26,518 \\
\hline Adjusted $\mathrm{R}^{2}$ & 0.045 & 0.050 & 0.049 & 0.053 \\
\hline \multicolumn{5}{|l|}{ Panel B. Bond rating } \\
\hline \multirow{4}{*}{$\begin{array}{l}\text { Dependent variable } \\
\text { Partition }\end{array}$} & (1) & (2) & (3) & (4) \\
\hline & NCSKEW $_{\mathrm{t}}$ & NCSKEW $_{\mathrm{t}}$ & DUVOL $_{t}$ & DUVOL $_{t}$ \\
\hline & High risk & Low risk & High risk & Low risk \\
\hline & (Unrated) & (Rated) & (Unrated) & (Rated) \\
\hline \multirow[t]{2}{*}{$\mathrm{ST} 3_{\mathrm{t}-1}$} & $-0.029 * *$ & $-0.040^{*}$ & $-0.016^{* * *}$ & $-0.020^{*}$ \\
\hline & $(-2.24)$ & $(-1.66)$ & $(-2.63)$ & $(-1.82)$ \\
\hline Controls & VIY & VIY & VIY & VIY \\
\hline $\mathrm{N}$ & 37,013 & 16,039 & 37,013 & 16,039 \\
\hline Adjusted $\mathrm{R}^{2}$ & 0.053 & 0.021 & 0.055 & 0.026 \\
\hline
\end{tabular}




\section{Appendix: Variable definitions}

\section{Crash risk variables}

$N C S K E W$ is the negative skewness of firm-specific weekly returns over the fiscal year.

DUVOL is the log of the ratio of the standard deviations of down-week to up-week firm-specific weekly returns.

For both crash risk variables, the firm-specific weekly return $(W)$ is equal to $\ln (1+$ residual $)$, where the residual is obtained from the following expanded market model:

$$
r_{j, \tau}=\alpha_{j}+\beta_{1, j} r_{m, \tau-1}+\beta_{2, j} r_{i, \tau-1}+\beta_{3, j} r_{m, \tau}+\beta_{4, j} r_{i, \tau}+\beta_{5, j} r_{m, \tau+1}+\beta_{6, j} r_{i, \tau+1}+\varepsilon_{j, \tau},
$$

where $r_{j, \tau}$ is the return on stock $j$ in week $\tau, r_{m, \tau}$ is the return on CRSP value-weighted market index, and $r_{i, \tau}$ is the Fama and French value-weighted industry index in week $\tau$.

\section{Debt maturity variables}

$S T 3$ is the ratio of debt in current liabilities (dlc) plus debt maturing in two or three years $(\mathrm{dd} 2+\mathrm{dd} 3)$ to total debt (the sum of debt in current liabilities plus long-term debt, i.e., dlc+dltt).

$S T 1$ is the ratio of debt in current liabilities (dlc) to total debt (dlc + dltt).

$S T 2$ is the ratio of debt in current liabilities (dlc) plus debt maturing in two years (dd2) to total debt $(\mathrm{dlc}+\mathrm{dltt})$.

ST5 is the ratio of debt in current liabilities (dlc) plus debt maturing in two to five years $(\mathrm{dd} 2+\mathrm{dd} 3+\mathrm{dd} 4+\mathrm{dd} 5)$ to total debt $(\mathrm{dl} c+\mathrm{dltt})$.

ST3_TA is the ratio of debt in current liabilities (dlc) plus debt maturing in two or three years $(\mathrm{dd} 2+\mathrm{dd} 3)$ to total assets (at).

STNP1 is the ratio of debt in current liabilities (dlc) minus long-term debt due in one year (dd1) to total debt $(\mathrm{dlc}+\mathrm{dltt})$.

DEBT_MAT is the natural logarithm of new private loan or public bond maturity, in days. Data source:

Mergent Fixed Income Securities Database (FISD) and DealScan.

$L O A N \_M A T$ is the natural logarithm of new private loan maturity, in days. Data source: DealScan.

WAVG_MAT is the natural logarithm of the issue-size-weighted debt maturity.

$A V G \_M A T$ is the natural logarithm of the equal-weighted debt maturity.

\section{Control variables}

$D T U R N$ is the average monthly share turnover over the current fiscal year minus the average monthly share turnover over the previous fiscal year, where monthly share turnover is calculated as the monthly trading volume divided by the total number of shares outstanding during the month.

SIGMA is the standard deviation of firm-specific weekly returns over the fiscal year. 
$R E T$ is the mean of firm-specific weekly returns over the fiscal year, times 100 .

$M B$ is the market value of equity (csho*prcc_f) divided by the book value of equity (market-to-book).

SIZE is the natural logarithm of market value of equity.

$L E V$ is total debt (dltt+dlc) divided by total assets (at).

$R O A$ is income before extraordinary items (ib) divided by total assets (at).

$A C C M$ is the absolute value of discretionary accruals estimated from the modified Jones model.

TERMSTR is the difference between the yield on 10-year government bonds and the yield on 6-month Treasury bills. Data source: Federal Reserve Bank of St. Louis.

$A B N E A R N$ is income before extraordinary items, minus common or ordinary stock (capital) equivalents (ibadj) in year $t+1$ and $t$, divided by the market value of equity in year $t$.

PAYOUT is the sum of common and preferred dividend and purchase ( $\mathrm{dvp}+\mathrm{dvc}+\mathrm{prstkc})$ divided by total assets (at).

$D E B T$ SIZE is the natural logarithm of the total amount of new private loans or the par value of new public bonds. Data sources: FISD and DealScan.

LOAN_SIZE is the natural logarithm of the total amount of new private loans. Data sources: DealScan.

$S U M \_S I Z E$ is the natural logarithm of the total amount of new loans or bond issues in year $t$.

EARNVOL is the standard deviation of the ratio of earnings, excluding extraordinary items and discontinued operations, to lagged total equity during the past five years.

CFVOL is the standard deviation of the ratio of cash flow to total assets during the past five years.

SALEVOL is the standard deviation of the ratio of sales to total assets during the past five years.

$B E T A$ is the beta risk from the CAPM, namely the covariance between the individual firm return and the market return divided by the variance of the market over a fiscal year.

\section{Conditioning variables}

INST is the percentage of shares held by institutional owners, obtained from the Thomson 13F database.

LTINST is the percentage of shares held by dedicated and quasi-indexer institutional investors.

GINDEX is the number of anti-takeover provisions based on Gompers et al. (2003). Anti-takeover provisions are obtained from the RiskMetrics' governance database.

FERR is the absolute value of the difference between actual earnings per share and consensus analyst forecast divided by consensus analyst forecast in year $t$.

DISPER is the standard deviation of analyst forecasts divided by consensus analyst forecast in year $t$.

$R D$ is the ratio of research and development expenditures (xrd) to total assets (at).

RATEDUM is an indicator variable that takes one if a firm has an S\&P rating on long-term debt (splticrm) and zero otherwise. 